DOE/ID-22250

Prepared in cooperation with the U.S. Department of Energy

\title{
lodine-129 in the Eastern Snake River Plain Aquifer at and near the Idaho National Laboratory, Idaho, 2017-18
}

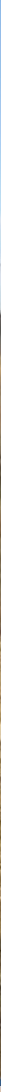

Scientific Investigations Report 2019-5133 
Cover: Photograph showing U.S. Geological Survey scientists collecting a water

sample at well USGS 45 at the Idaho National Laboratory, Idaho. (Photograph by Amy Wehnke, U.S. Geological Survey, October 2, 2018.) 


\section{lodine-129 in the Eastern Snake River Plain Aquifer at and near the Idaho National Laboratory, Idaho, 2017-18}

By Neil V. Maimer and Roy C. Bartholomay

DOE-ID 22250

Prepared in cooperation with the U.S. Department of Energy

Scientific Investigations Report 2019-5133 


\title{
U.S. Department of the Interior DAVID BERNHARDT, Secretary
}

\author{
U.S. Geological Survey \\ James F. Reilly II, Director
}

U.S. Geological Survey, Reston, Virginia: 2019

For more information on the USGS - the Federal source for science about the Earth, its natural and living resources, natural hazards, and the environment-visit https://www.usgs.gov or call 1-888-ASK-USGS.

For an overview of USGS information products, including maps, imagery, and publications, visit https://store.usgs.gov.

Any use of trade, firm, or product names is for descriptive purposes only and does not imply endorsement by the U.S. Government.

Although this information product, for the most part, is in the public domain, it also may contain copyrighted materials as noted in the text. Permission to reproduce copyrighted items must be secured from the copyright owner.

Suggested citation:

Maimer, N.V., and Bartholomay, R.C., 2019, Iodine-129 in the eastern Snake River Plain aquifer at and near the Idaho National Laboratory, Idaho, 2017-18: U.S. Geological Survey Scientific Investigations Report 2019-5133, 20 p., https://doi.org/10.3133/sir20195133.

ISSN 2328-0328 (online) 


\section{Contents}

Abstract

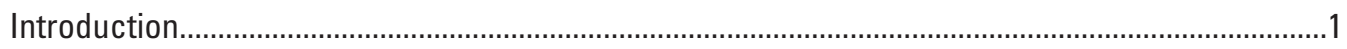

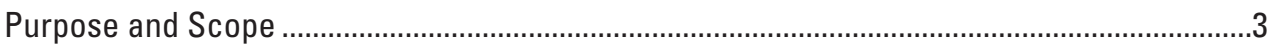

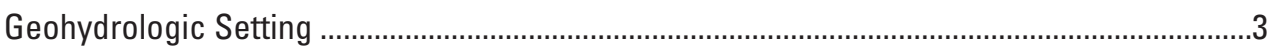

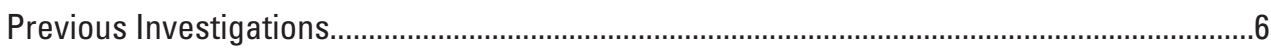

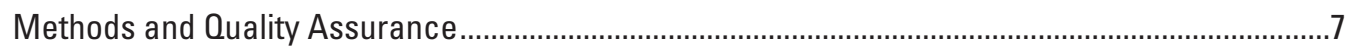

Sample Collection Methods .................................................................................................

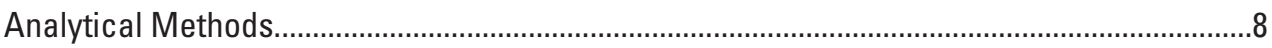

Guidelines for Interpretation of Analytical Results ...................................................................

Quality Assurance/Quality Control.......................................................................................

Concentrations of lodine-129 in the Eastern Snake River Plain Aquifer .........................................

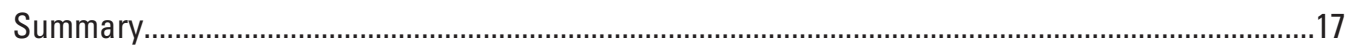

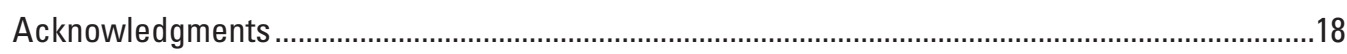

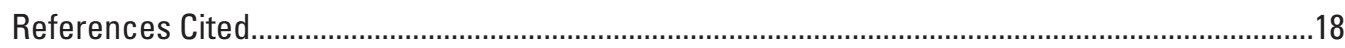

\section{Figures}

1. Map showing location of the Idaho National Laboratory and selected facilities, Idaho 2

2. Map showing location of selected wells at and near the Idaho National

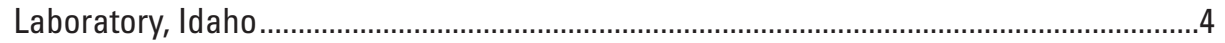

3. Map showing location of wells at and near the Idaho Nuclear Technology and Engineering Center, Idaho National Laboratory, Idaho ....................................................5

4. Map showing areal distribution of iodine-129 in the eastern Snake River Plain aquifer at the Idaho National Laboratory, Idaho, 2017-18 ..............................................11

5. Map showing change in concentration of iodine-129 between samples collected during 2011-12 and 2017-18, Idaho National Laboratory and vicinity, Idaho ..................14

6. Map showing change in concentration of iodine-129 between samples collected between 2011-12 and 2017-18 in the Idaho Nuclear Technology and Engineering Center area, Idaho.

7. Graphs showing concentration trends of iodine-129 at selected wells at and near the Idaho National Laboratory, Idaho.

\section{Tables}

1. Iodine-129 concentrations in groundwater, Idaho National Laboratory and vicinity, 2017-18

2. Concentrations of lodine-129 in water from selected wells, Idaho National Laboratory and vicinity, 1990-2018

3. Iodine-129 concentrations in groundwater wells located various distances from the Idaho Nuclear Technology and Engineering Center and changes in concentration from the 2011-12 study, Idaho National Laboratory and vicinity, Idaho. 


\section{Conversion Factors}

U.S. customary units to International System of Units

\begin{tabular}{lll}
\hline \multicolumn{1}{c}{ Multiply } & By & \multicolumn{1}{c}{ To obtain } \\
\hline foot $(\mathrm{ft})$ & \multicolumn{1}{c}{ Length } & \\
mile $(\mathrm{mi})$ & 0.3048 & meter $(\mathrm{m})$ \\
& 1.609 & kilometer $(\mathrm{km})$ \\
\hline acre & Area & \\
square mile $\left(\mathrm{mi}^{2}\right)$ & 4,047 & square meter $\left(\mathrm{m}^{2}\right)$ \\
\hline & 2.590 & square kilometer $\left(\mathrm{km}^{2}\right)$ \\
\hline acre-foot per day $(\mathrm{acre}-\mathrm{ft} / \mathrm{d})$ & Flow rate & \\
foot per second $(\mathrm{ft} / \mathrm{s})$ & 0.01427 & cubic meter per second $\left(\mathrm{m}^{3} / \mathrm{s}\right)$ \\
foot per day $(\mathrm{ft} / \mathrm{d})$ & 0.3048 & meter per second $(\mathrm{m} / \mathrm{s})$ \\
cubic foot per second $(\mathrm{ft} / \mathrm{s})$ & 0.3048 & meter per day $(\mathrm{m} / \mathrm{d})$ \\
gallon per minute $(\mathrm{gal} / \mathrm{min})$ & 0.02832 & cubic meter per second $\left(\mathrm{m}^{3} / \mathrm{s}\right)$ \\
\hline & 0.06309 & liter per second $(\mathrm{L} / \mathrm{s})$ \\
\hline picocurie per liter $(\mathrm{pCi} / \mathrm{L})$ & Radioactivity & \\
\hline & 0.037 & becquerel per liter $(\mathrm{Bq} / \mathrm{L})$ \\
\hline foot squared per day $\left(\mathrm{ft}{ }^{2} / \mathrm{d}\right)$ & Transmissivity & \\
\hline
\end{tabular}

\section{Datums}

All study wells except for USGS 144 were surveyed using the North American Datum of 1927 (NAD 27) and the National Geodetic Vertical Datum of 1929 (NGVD 29). For USGS 144, the North American Vertical Datum of 1988 (NAVD 88) and the North American Datum of 1983 (NAD 83) were used. 


\section{Abbreviations}

$\begin{array}{ll}\text { AMS } & \text { lodine-129 } \\ \text { ATRC } & \text { accelerator mass spectrometry } \\ \text { CFA } & \text { Advanced Test Reactor Complex } \\ \text { Ci } & \text { Central Facilities Area } \\ \text { DOD } & \text { curie } \\ \text { DOE } & \text { U.S. Department of Defense } \\ \text { ESRP } & \text { U.S. Department of Energy } \\ \text { INL } & \text { eastern Snake River Plain } \\ \text { INTEC } & \text { Idaho National Laboratory } \\ \text { MCL } & \text { Idaho Nuclear Technology and Engineering Center } \\ \text { PRIME Lab } & \text { maximum contaminant level } \\ \text { RWMC } & \text { Purdue Rare Isotope Measurement Laboratory } \\ \text { USEPA } & \text { Radioactive Waste Management Complex } \\ \text { USGS } & \text { U.S. Environmental Protection Agency }\end{array}$





\title{
lodine-129 in the Eastern Snake River Plain Aquifer at and near the Idaho National Laboratory, Idaho, 2017-18
}

\author{
By Neil V. Maimer and Roy C. Bartholomay
}

\section{Abstract}

From 1953 to 1988 , approximately 0.941 curies of iodine-129 $\left({ }^{129} \mathrm{I}\right)$ were contained in wastewater generated at the Idaho National Laboratory, with almost all of it discharged at or near the Idaho Nuclear Technology and Engineering Center (INTEC). Until 1984, most of the wastewater was discharged directly into the eastern Snake River Plain (ESRP) aquifer through a deep disposal well; however, some wastewater was also discharged into unlined infiltration ponds or leaked from distribution systems below the INTEC.

During 2017-18, the U.S. Geological Survey, in cooperation with the U.S. Department of Energy, collected samples for ${ }^{129}$ I from 30 wells that monitor the ESRP aquifer to track concentrations and changes of the carcinogenic radionuclide that has a 15.7 million-year half-life. Concentrations of ${ }^{129} \mathrm{I}$ in the aquifer ranged from 0.000016 \pm 0.000001 to $0.88+/-0.03$ picocuries per liter $(\mathrm{pCi} / \mathrm{L})$, and concentrations generally decreased in wells near the INTEC as compared with previously collected samples. The average concentration of 15 wells sampled during 5 different sample periods decreased from $1.15 \mathrm{pCi} / \mathrm{L}$ in $1990-91$ to 0.168 $\mathrm{pCi} / \mathrm{L}$ in $2017-18$, but average concentrations were similar to 2011-12 within analytical uncertainty. All but four wells within a 3-mile radius of the INTEC showed decreases in concentration, and all samples had concentrations less than the U.S. Environmental Protection Agency's maximum contaminant level of $1 \mathrm{pCi} / \mathrm{L}$. These decreases are attributed to the discontinuation of disposal of ${ }^{129} \mathrm{I}$ in wastewater and to dilution and dispersion in the aquifer. Some wells southeast of INTEC showed increasing trends; these increases were attributed to variable transmissivity.

Although wells near INTEC sampled in 2017-18 showed decreases in concentrations compared with data collected previously, some wells south of the INL boundary showed small increases. These increases are attributed to historical variable discharge rates of wastewater that eventually moved to these well locations as a pulse of water from a particular disposal period.

\section{Introduction}

The Idaho National Laboratory (INL), encompassing about 890 square miles $\left(\mathrm{mi}^{2}\right)$ of the eastern Snake River Plain (ESRP) in southeastern Idaho (fig. 1), is operated by the U.S. Department of Energy (DOE). The INL was established in 1949 for the development of atomic energy applications, nuclear safety research, defense programs, environmental research, and advanced energy concepts. Until 1993, uranium from spent nuclear fuel elements from government-owned reactors was recovered after reprocessing at the Idaho Nuclear Technology and Engineering Center (INTEC; fig. 1). As part of the fuel reprocessing activities, several fission products were released in wastewater at the INTEC. Iodine-129 $\left({ }^{129} \mathrm{I}\right)$, produced by the fission of uranium-235 and plutonium-239, was one of the products released in wastewater. Prior to 1984, most of the wastewater generated at the INTEC was injected directly to the ESRP aquifer through a 598-foot-deep disposal well. Beginning in February 1984, routine use of the disposal well was discontinued, and wastewater was discharged to unlined infiltration ponds south of INTEC, which allow the wastewater to percolate through about 450 feet (ft) of basalt and sediment to the aquifer.

Iodine-129 in the ESRP aquifer originates from atmospheric deposition, rock weathering, and wastewater disposal (Mann and Beasley, 1994a). The amount of ${ }^{129} \mathrm{I}$ in the aquifer from atmospheric deposition and rock weathering is considered small and is included in the estimated background concentration of 0.0000054 picocuries per liter $(\mathrm{pCi} / \mathrm{L})$ in the ESRP aquifer in eastern Idaho (Cecil and others, 2003). Mann and Beasley (1994a) reported that wastewater discharged to the injection well and infiltration ponds at the INTEC between 1953 and 1990 contained an estimated $0.56-1.18$ curies (Ci) of ${ }^{129} \mathrm{I}$. A more detailed estimate of wastewater discharge to the injection well through 1984 was performed by the DOE Idaho Operations Office (U.S. Department of Energy, 2004, appendix B), and results indicated that a maximum of 0.86 $\mathrm{Ci}$ was discharged to the aquifer. Additionally, about $0.08 \mathrm{Ci}$ of ${ }^{129} \mathrm{I}$ were discharged to the infiltration ponds from 1984 to 1988 (Litteer, 1988; Mann and others, 1988, table 2; Litteer and Reagan, 1989), and about $0.001 \mathrm{Ci}$ of ${ }^{129} \mathrm{I}$ was released at the INTEC Tank Farm between 1958 and 1986 (Cahn and others, 2006, table 5-2). Thus, the revised total from INTEC 

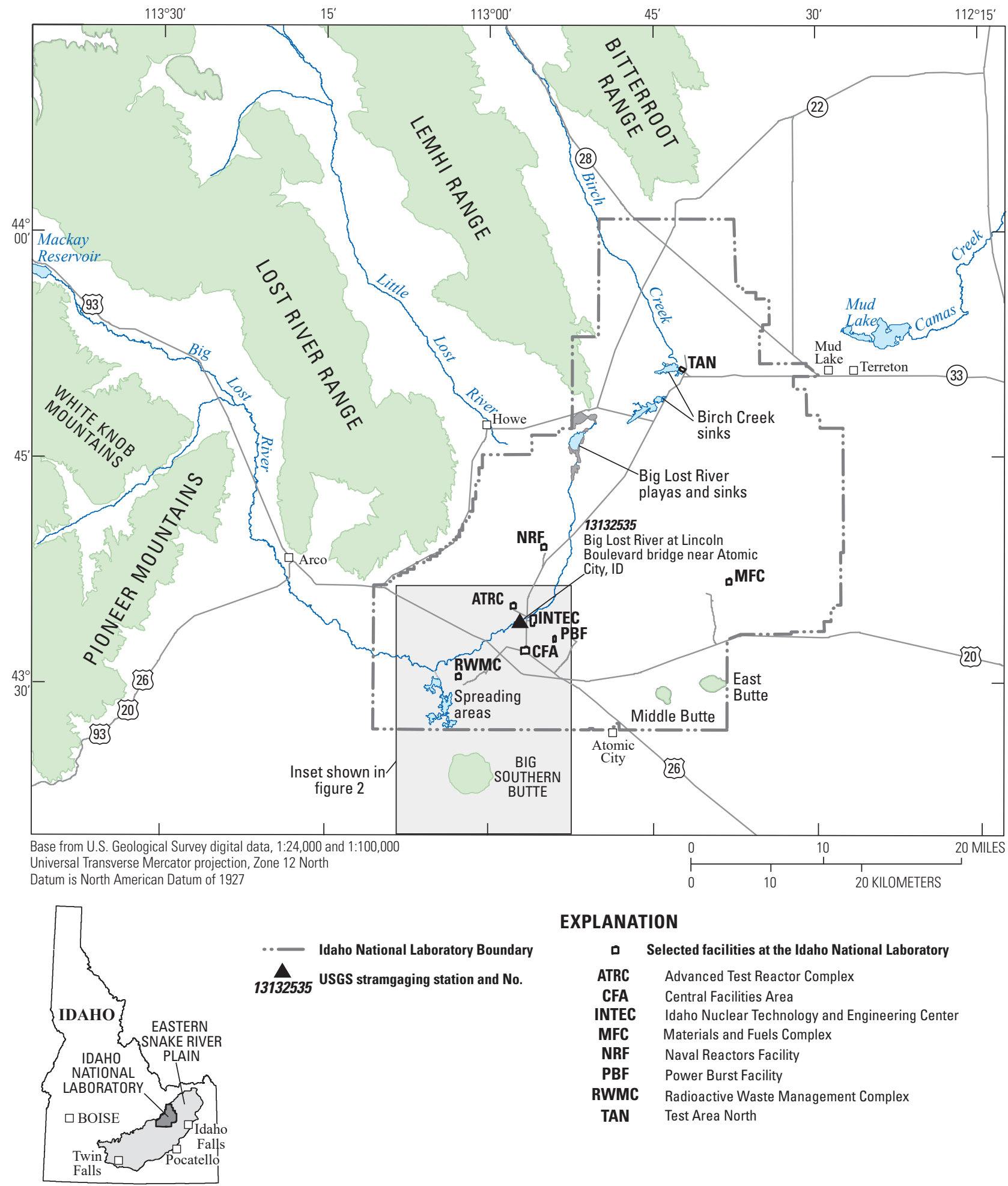

EXPLANATION

$\begin{array}{cc}\text { 口 } & \text { Selected facilities at the Idaho National Laboratory } \\ \text { ATRC } & \text { Advanced Test Reactor Complex } \\ \text { CFA } & \text { Central Facilities Area } \\ \text { INTEC } & \text { Idaho Nuclear Technology and Engineering Center } \\ \text { MFC } & \text { Materials and Fuels Complex } \\ \text { NRF } & \text { Naval Reactors Facility } \\ \text { PBF } & \text { Power Burst Facility } \\ \text { RWMC } & \text { Radioactive Waste Management Complex } \\ \text { TAN } & \text { Test Area North }\end{array}$

Figure 1. Location of the Idaho National Laboratory and selected facilities, Idaho. 
is about $0.941 \mathrm{Ci}$. Additionally, some ${ }^{129} \mathrm{I}$ may still be present in perched groundwater zones around the INTEC. Some ${ }^{129} \mathrm{I}$ also was discharged into the radioactive waste ponds at the Advanced Test Reactor Complex (ATRC), but annual concentrations of the discharge water generally were much less than $1 \mathrm{pCi} / \mathrm{L}$; for example, EG\&G Idaho, Inc. (1979), showed an average annual concentration of $0.0000128 \mathrm{pCi} / \mathrm{L}$ in the 1978 discharge water.

Iodine-129 is a carcinogen, and communities downgradient of the INL may be concerned that ${ }^{129}$ I disposed at the INL could be a hazard to their health. Because of its 15.7 million-year half-life, ${ }^{129}$ I released to the environment is a permanent addition to the global inventory (Mann and Beasley, 1994a). The U.S. Environmental Protection Agency (USEPA) maximum contaminant level (MCL) for ${ }^{129} \mathrm{I}$ in drinking water is $1 \mathrm{pCi} / \mathrm{L}$ (U.S. Environmental Protection Agency, 2015, Table of Derived Concentrations of Beta and Photon Emitters in Drinking Water). The MCL is based on the average concentration in a public drinking water supply that will yield an annual whole-body dose equivalent of 4 millirem per year (mrem/year). Each man-made nuclide has a different concentration of radiation, measured in $\mathrm{pCi} / \mathrm{L}$, which produces the $4 \mathrm{mrem} /$ year dose.

To provide information to evaluate the potential hazards, the U.S. Geological Survey (USGS), in cooperation with the DOE, has periodically monitored for ${ }^{129} \mathrm{I}$ in groundwater from the ESRP aquifer at and downgradient of the INTEC since 1977. Monitoring programs from 1977, 1981, 1986, 1990-91, 2003, 2007, and 2010-12 were summarized by Mann and others (1988), Mann and Beasley (1994b), Bartholomay (2009) and (2013). This report summarizes concentrations in the ESRP aquifer from 2017-18.

\section{Purpose and Scope}

The USGS collected water samples from wells during autumn 2017 and spring 2018 to evaluate concentrations of ${ }^{129} \mathrm{I}$ in the ESRP aquifer. The 30 wells that were sampled were used to monitor the ESRP aquifer at and near the INL. The wells sampled were completed as open-hole monitoring wells in the upper 50-200 ft of the ESRP aquifer from depths ranging from about 460 to $800 \mathrm{ft}$ below land surface. In October 2017, 18 samples were collected from 16 wells, and in April 2018 an additional 16 samples were collected from 14 wells (figs. 2 and 3). Four replicates were collected as a measure of quality assurance/quality control (QA/QC). Samples were analyzed using accelerator mass spectrometry (AMS) at the Purdue Rare Isotope Measurement Laboratory (PRIME Lab), Purdue University, West Lafayette, Indiana. This method is described on the PRIME Lab website, "AMS is an ultra-sensitive analytical technique for measuring longlived radionuclides" (Purdue Rare Isotope Measurement Laboratory, 2019).
This report documents the analytical results for these samples, presents an analysis of the results, describes the distribution and concentration of ${ }^{129} \mathrm{I}$, and provides a comparison to the results of previous studies.

\section{Geohydrologic Setting}

The INL is located above the west-central part of the ESRP. The ESRP is a northeast-trending structural basin about 200-mile (mi) long and 50-70 mi wide (fig. 1). The basin, bounded by faults on the northwest and by downwarping and faulting on the southeast, has been filled with basaltic lava flows interbedded with terrestrial sediments. The basaltic rocks and sedimentary deposits combine to form the ESRP aquifer, which is the main source of groundwater on the plain.

The ESRP aquifer is one of the most productive aquifers in the United States (U.S. Geological Survey, 1985, p. 193). Movement of water in the aquifer generally is from northeast to southwest, and water eventually discharges to springs along the Snake River downstream of Twin Falls, Idaho-about $100 \mathrm{mi}$ southwest of the INL. Water moves horizontally through basalt interflow zones and vertically through joints and interfingering edges of interflow zones. Infiltration of surface water, heavy pumpage, geologic conditions, and seasonal fluxes of recharge and discharge locally affect the movement of groundwater (Garabedian, 1986). Recharge to the ESRP aquifer is primarily from infiltration of applied irrigation water, infiltration of streamflow, groundwater inflow from adjoining mountain drainage basins, and infiltration of precipitation.

At the INL, depth to water in wells completed in the ESRP aquifer ranges from about $200 \mathrm{ft}$ in the northern part of the site to more than $900 \mathrm{ft}$ in its southeastern part. A significant proportion of the groundwater moves through the upper 200-800 ft of basaltic rocks (Mann, 1986, p. 21). Ackerman (1991, p. 30) and Bartholomay and others (1997, table 3) reported a range of transmissivity of basalt in the upper part of the aquifer of 1.1-760,000 foot squared per day $\left(\mathrm{ft}^{2} / \mathrm{d}\right)$. The hydraulic gradient at the INL ranges from 2 to 10 feet per mile (ft/mi), with an average of about $4 \mathrm{ft} /$ mi (Bartholomay and others, 2017, fig. 9). Horizontal flow velocities of 2-20 ft/d have been calculated based on the movement of various constituents in several areas of the aquifer at the INL (Robertson and others, 1974; Mann and Beasley, 1994b; Cecil and others, 2000; Busenberg and others, 2001). These flow rates equate to a travel time of about 70-700 years for water beneath the INL to travel to springs that discharge at the terminus of the ESRP aquifer near Twin Falls, Idaho (fig. 1). Localized tracer tests at the INL have shown vertical and horizontal transport rates as high as 60-150 ft/day (Nimmo and others, 2002; Duke and others, 2007). 


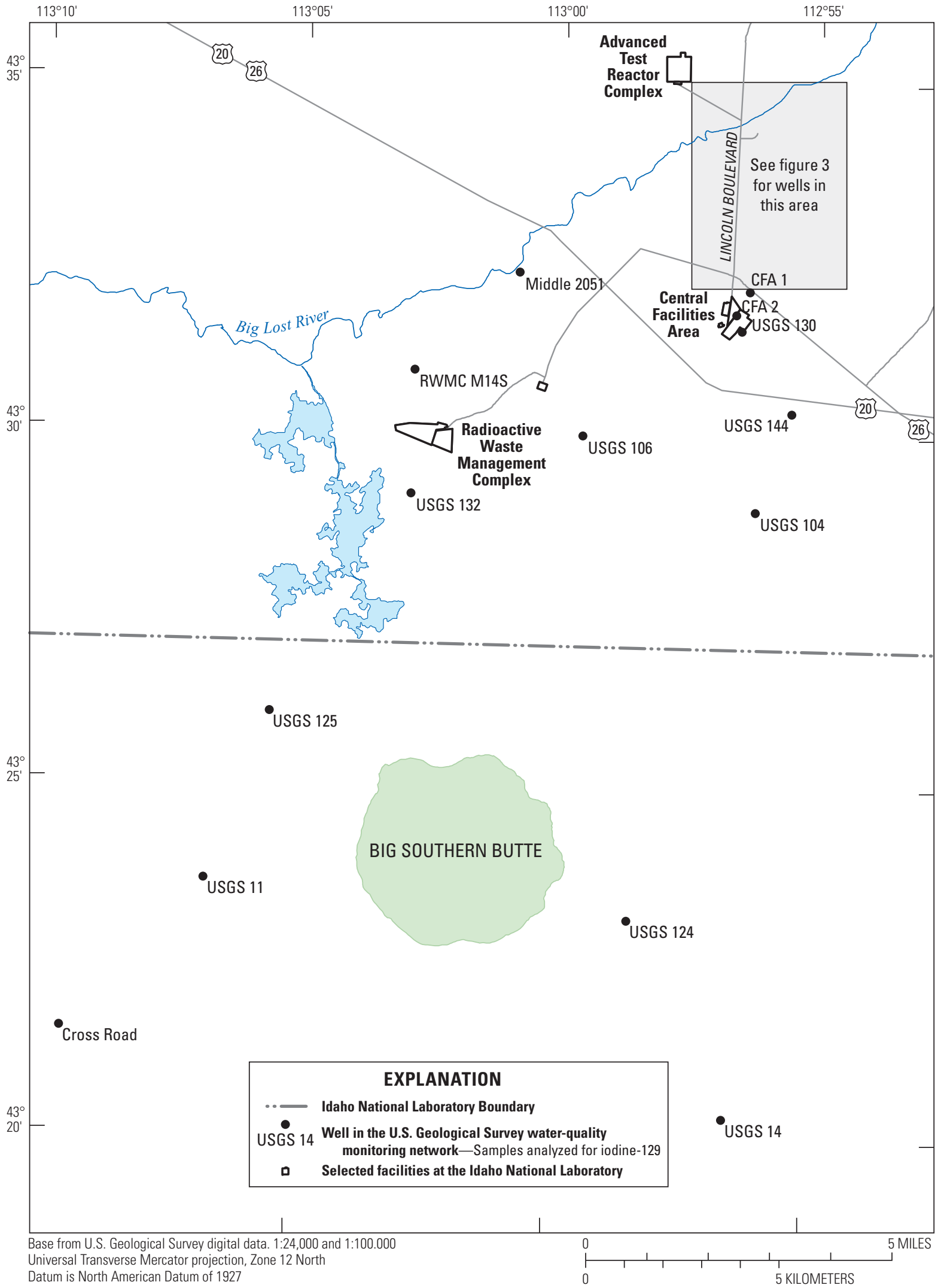

Figure 2. Location of selected wells at and near the Idaho National Laboratory, Idaho. 


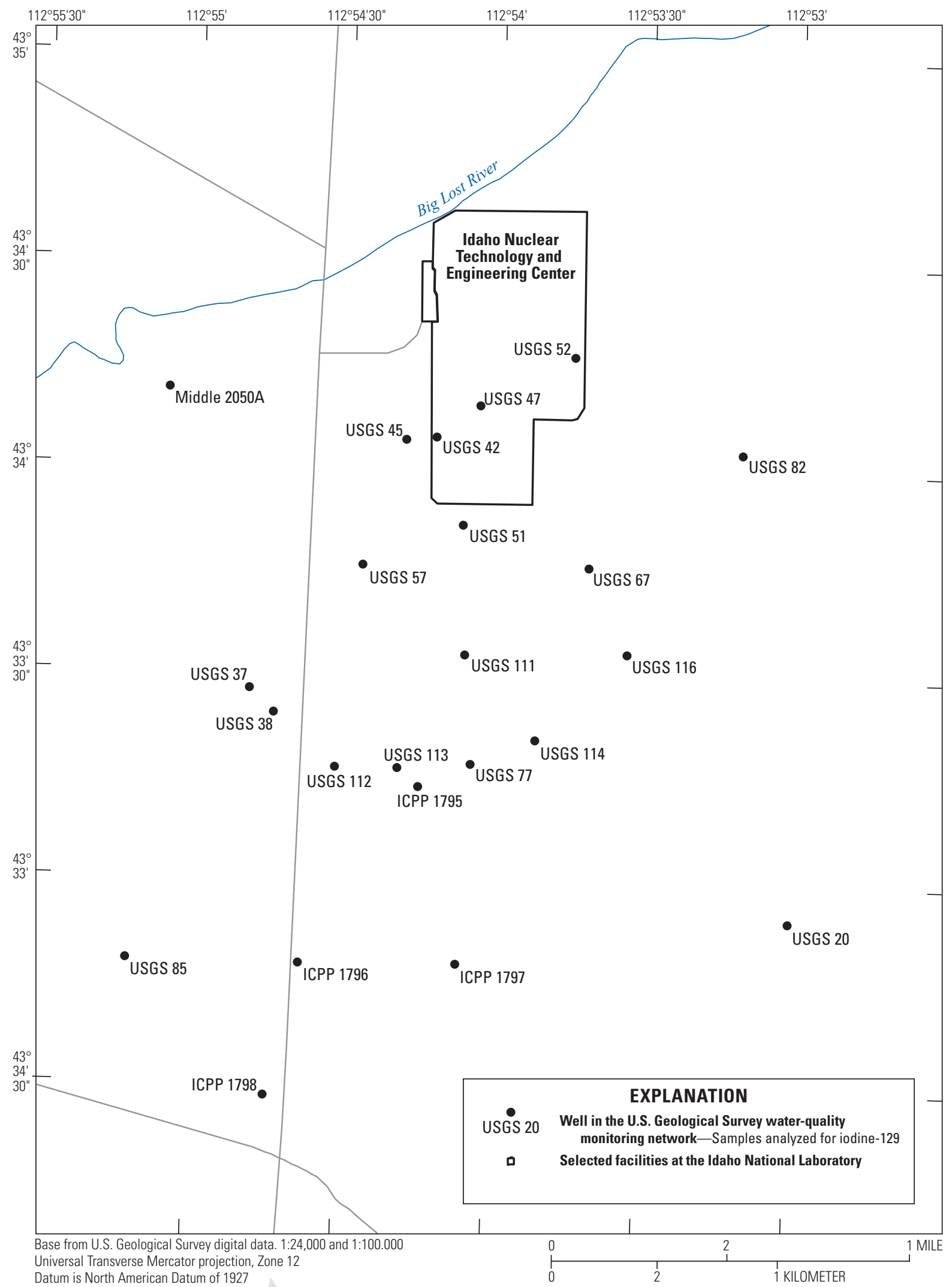

Figure 3. Location of wells at and near the Idaho Nuclear Technology and Engineering Center, Idaho National Laboratory, Idaho. 


\section{Previous Investigations}

There have been many evaluations of the geology and hydrology of the ESRP aquifer at the INL. A comprehensive listing of publications by the USGS at the INL is available at U.S. Geological Survey (2019).

Previous investigations of ${ }^{129} \mathrm{I}$ in water from the ESRP aquifer include those by Barraclough and others (1982), Lewis and Jensen (1985), Mann and others (1988), Mann and Beasley (1994a; 1994b), Cecil and others (2003), U.S. Department of Energy (2004, 2007, 2008, 2012), Hall (2006), Forbes and others (2007), Bartholomay $(2009,2013)$, and Shanklin and others (2017). Results from April 1977 sampling for ${ }^{129} \mathrm{I}$ in 14 wells indicated concentrations ranged from 0.9 to $27 \mathrm{pCi} / \mathrm{L}$ for statistically positive values (Barraclough and others, 1982, fig. 42), and since discharge began in 1953, ${ }^{129} \mathrm{I}$ was identified in wells less than $3 \mathrm{mi}$ from the disposal well. In October 1981, concentrations of ${ }^{129}$ I ranged from 0.05 to $41 \mathrm{pCi} / \mathrm{L}$ for statistically positive values (Lewis and Jensen, 1985), and since discharge began in $1953,{ }^{129} \mathrm{I}$ was identified in wells about $6.3 \mathrm{mi}$ from the disposal well. The major difference between the 1977 and 1981 results was that the sample size was increased from 1 to $4 \mathrm{~L}$ for a four-fold reduction in the reporting level. The increase in sensitivity of analyses (Lewis and Jensen, 1985), along with a more extensive set of wells sampled (20 in 1977 and 32 in 1981), were the primary reasons for the increase in the size of the ${ }^{129} \mathrm{I}$ plume. In August 1986, ${ }^{129}$ I concentrations from 20 wells that were greater than the reporting level (Mann and others, 1988) ranged from $0.49 \pm 0.12$ to $3.6 \pm 0.4 \mathrm{pCi} / \mathrm{L}$ and had migrated about the same distance from the disposal well as in 1981. The large decrease in the maximum concentration between 1981 and 1986 was attributed to changes in disposal practices at the INTEC, reduction in the mass of ${ }^{129} \mathrm{I}$ in wastewater, and to increased dilution in the mid-1980s from a large amount of flow in the Big Lost River (Mann and others, 1988).

Prior to the 1990-91 data collection, neutron activation methods were used for analyses. During 1990-91, Mann and Beasley (1994b) collected samples from 51 wells at and near the INL and analyzed the samples using an AMS method. The AMS method allowed for increased sensitivity of the analyses (two to six times more sensitive than neutron activation). The increased sensitivity allowed for determining a background concentration of $0.0000009 \pm 0.0000002 \mathrm{pCi} / \mathrm{L}$ from a sample located upgradient from the INTEC. The increased sensitivity resulted in detectable concentrations of ${ }^{129} \mathrm{I}$ downgradient of the INL that were used to calculate groundwater flow velocities of at least $6 \mathrm{ft} / \mathrm{d}$. The maximum concentration detected in 1990-91 samples was $3.82 \pm 0.19 \mathrm{pCi} / \mathrm{L}$, which was similar to the maximum concentration detected in 1986; however, mean concentrations from 18 wells sampled in 1986 and 1990-91 decreased from $1.30 \pm 0.26$ to $0.81 \pm 0.19 \mathrm{pCi} / \mathrm{L}$ (Mann and Beasley, 1994b). This decrease was attributed largely to a decrease in disposal rates.
In 1992, Mann and Beasley (1994a) collected groundwater and surface-water samples from 16 sites not likely to have been affected by wastewater disposal at the INTEC to determine background concentrations of ${ }^{129} \mathrm{I}$. Concentrations in water from nine wells, four springs, and three streams on or tributary to the ESRP ranged from $0.0000001 \pm 0.0000001$ to $0.0000081 \pm 0.0000006 \mathrm{pCi} / \mathrm{L}$ (average of $0.0000033 \pm 0.0000021 \mathrm{pCi} / \mathrm{L}$ ). At the 99 -percent confidence level, background concentrations for the 16 sites were estimated to be less than or equal to 0.0000082 $\mathrm{pCi} / \mathrm{L}$. Cecil and others (2003) reevaluated the background concentrations by analyzing results of 52 samples collected from groundwater and surface water in 1992-94 from various locations in the ESRP in southeastern Idaho, and includes the samples collected by Mann and Beasley (1994a). Cecil and others (2003) determined that surface water samples generally contained larger ${ }^{129} \mathrm{I}$ concentrations than groundwater samples because of anthropogenic fallout and evapotranspiration. Using a subset of 30 water samples from wells, they determined a background concentration of $0.0000054 \mathrm{pCi} / \mathrm{L}$ with a 95-percent nonparametric confidence interval of 0.0000052 to $0.00001 \mathrm{pCi} / \mathrm{L}$.

Hall (2006) collected samples from 13 sites downgradient of the INL during 1997 and 1998. Using AMS methods, Hall (2006) determined that concentrations in four of the sites-USGS 11, 14, 124, and 125 (fig. 2) -were greater than estimated background concentrations, and he postulated that the 1958 peak ${ }^{129}$ I concentration in the ESRP aquifer had already passed these wells. Concentrations of the four sites ranged from $0.0000061 \pm 0.00000018$ to $0.00074 \pm 0.00003$ $\mathrm{pCi} / \mathrm{L}$, but they were less than concentrations measured in 1991 and 1993.

INL contractors routinely collect ${ }^{129}$ f from monitoring wells throughout the INL for their Waste Area Group monitoring programs at the INL. In 2002, samples were collected from four wells south of the INTEC (ICPP 1795-98, fig. 3) from three zones in the aquifer to determine concentrations above and below the H-I interbed (U.S. Department of Energy, 2004). Concentrations of ${ }^{129} \mathrm{I}$ in well ICPP-1795 increased from $0.34 \pm 0.04 \mathrm{pCi} / \mathrm{L}$ at $560 \mathrm{ft}$ below land surface to $0.43 \pm 0.07 \mathrm{pCi} / \mathrm{L}$ at $620 \mathrm{ft}$ below land surface. The three wells farther to the south showed a decrease in ${ }^{129}$ I concentration with depth, with concentrations in the upper zone ranging from $0.58 \pm 0.1$ to $0.88 \pm 0.08 \mathrm{pCi} / \mathrm{L}$ and concentrations in the lower zone ranging from not detected to $0.33 \pm 0.05 \mathrm{pCi} / \mathrm{L}$. The U.S. Department of Energy (2004, fig. 5-5) also presented results from analyses of 49 wells sampled in 2001; concentrations ranged from less than the method detection level of approximately 0.1 to $1.06 \mathrm{pCi} / \mathrm{L}$. Analyses were completed using gamma spectroscopy methods. Concentrations for 20 sites sampled in 2003 were all less than the MCL of $1 \mathrm{pCi} / \mathrm{L}$ (U.S. Department of Energy, 2004, fig. 6-1). 
Forbes and others (2007) presented results for 25 wells sampled in 2006 near the INTEC; concentrations ranged from less than the reporting level to $0.65 \pm 0.097 \mathrm{pCi} / \mathrm{L}$ in USGS 67. Analyses of data collected from 2004-06 at wells around the INTEC indicated no discernible change in the concentrations when the uncertainty of the data was considered.

U.S. Department of Energy (2007) presented results for ${ }^{129} \mathrm{I}$ data collected in 2005 and 2006 from 24 wells downgradient of the INTEC and the ATRC (including several wells south of the INL), along with results from 5 zones each from two Westbay ${ }^{\mathrm{TM}}$ equipped wells (Middle 2050A and Middle 2051). Samples were analyzed using the AMS method at the PRIME Lab in Indiana, and some comparison was made to the 2003 USGS data presented in Bartholomay (2009). Results were used to speculate on the source of ${ }^{129} \mathrm{I}$ in wells around the RWMC. Concentrations in most southern wells were greater than background concentrations.

U.S. Department of Energy (2008) presented results for ${ }^{129} \mathrm{I}$ data collected in 2007 from six zones in one Westbay ${ }^{\mathrm{TM}}$ equipped well (USGS 132). Samples were analyzed using the AMS method at the PRIME Lab in Indiana, and the results from the six zones ranged from $0.0004 \pm 0.000013$ to $0.002 \pm$ $0.00009 \mathrm{pCi} / \mathrm{L}$. Results for all six zones were more than two orders of magnitude less than the MCL.

Bartholomay (2009) presented results for ${ }^{129} \mathrm{I}$ data collected in 2003 from 36 wells and data collected in 2007 from 36 wells along with concentrations from 31 zones sampled from six wells equipped with multilevel monitoring systems. Samples were analyzed using the AMS method at the PRIME Lab in Indiana, and concentrations ranged from $0.0000066+/-0.0000002$ to $1.16+/-0.04 \mathrm{pCi} / \mathrm{L}$. The report highlighted concentration increases and decreases through time at various parts of the INL. Decreases were attributed to discontinued disposal and dilution and dispersion in the aquifer. Increases were attributed to variable discharge rates of wastewater that eventually moved to well locations as a mass of water from a particular disposal period, and from the possible movement of remnant concentrations in perched aquifers around INTEC infiltrating to the ESRP aquifer.

U.S. Department of Energy (2012) presented results for ${ }^{129} \mathrm{I}$ data collected in 2011 from wells in and around INTEC. Concentrations were less than the MCL at all the monitoring wells, and most of the wells had concentrations below the laboratory detection levels. The highest concentration $(0.537 \mathrm{pCi} / \mathrm{L})$ was detected in well USGS 67 . Trend plots indicated that ${ }^{129} \mathrm{I}$ concentrations decreased significantly from concentrations observed during the 1980s and 1990s (U.S. Department of Energy, 2012, p.27).

Bartholomay (2013) presented results for ${ }^{129}$ I data collected from 2010 through 2012 at and downgradient of the INL from 62 wells. Eleven of the 62 wells were multi-level monitoring wells that had 25 samples collected from various zones. Concentrations of ${ }^{129} \mathrm{I}$ in the aquifer ranged from $0.0000013+/-0.0000005$ to $1.02+/-0.04 \mathrm{pCi} / \mathrm{L}$ and generally decreased in wells near INTEC relative to previous sampling events. The smallest concentration was collected in a firsttime sample collected from a well near Kimama, Idaho, and first-time samples were also collected from wells near the Naval Reactors Facility, the ATRC, and several multi-level monitoring wells.

Results of FY2016 groundwater monitoring performed to implement the CERCLA remedy at the INTEC were presented in a report by Shanklin and others (2017). Results of sampling at 16 aquifer wells and 5 shallow perched aquifer wells showed ${ }^{129}$ I detections at 2 aquifer wells, both below USEPA MCLs. The report also stated that when taking analytical uncertainties into account, none of the wells showed a significant ${ }^{129} \mathrm{I}$ concentration increase.

\section{Methods and Quality Assurance}

\section{Sample Collection Methods}

Water was collected from wells with dedicated submersible pumps, apart from two production wells located in the Central Facilities Area (CFA). Water samples were collected according to proceedures described in the USGS National Field manual (U.S. Geological Survey, variously dated) and the USGS INL Project Office quality assurance plan (Bartholomay and others, 2014). At least one borehole volume of water was purged from each well, and field measurements had stabilized prior to collecting samples. Prior to October 2003, samples were collected following stable field measurements and after three volumes of water were purged, but studies conducted by Bartholomay (1993) and Knobel (2006) determined that the difference between purging one and three wellbore volumes at selected INL wells had no discernible effect on the statistical comparability of select water-quality data. Those studies, however, did not examine the possible effects on ${ }^{129} \mathrm{I}$ data.

To ensure that particulate matter would not affect the laboratory preparation of the silver-iodide targets used in the AMS measurements of ${ }^{129} \mathrm{I}$ (Cecil and others, 2003), all samples were filtered through a disposable 0.45 -micrometer filter cartridge that had been pre-rinsed with at least $2 \mathrm{~L}$ of deionized water and an additional amount of sample water prior to sample collection. Samples were collected over a several week period, so each sample was preserved with a potassium hydroxide and sulfurous acid stabilizer solution, stored until sampling completion and then sent for processing as one shipment to the laboratory. 


\section{Analytical Methods}

All samples were sent to the PRIME Lab at Purdue University, West Lafayette, Indiana, where ${ }^{129}$ I concentrations were determined by AMS methods described on the PRIME Lab website (Purdue Rare Isotope Measurement Laboratory, 2019) and by Sharma and others (1997, 2000). Quality control procedures are described by Mark W. Caffee, Director of PRIME Lab (Caffee, 2019). Water samples go through a chemical process to produce a silver iodide (AgI) target material that is mixed with an equal volume of Niobium $(\mathrm{Nb})$, which serves as a binder material. The samples are then loaded into aluminum cathodes for AMS analysis. Analyses of the targets produce a ratio of ${ }^{129} \mathrm{I}$ to stable iodine-127 $\left({ }^{127} \mathrm{I}\right)$ and associated uncertainties. Calculated concentrations and analytical uncertainties are derived from the ${ }^{129} \mathrm{I}$ to ${ }^{127} \mathrm{I}$ ratios into units of picocuries of ${ }^{129} \mathrm{I}$ per liter of water $(\mathrm{pCi} / \mathrm{L})$.

For this study, the laboratory reported results in $\mathrm{pCi} / \mathrm{L}$ based on the equation:

$$
\frac{p C i}{L}(\text { sample })=\frac{\left(R_{s}-R_{b}\right)\left(W_{s}+W_{c}\right) 1.80 \times 10^{-7}}{W t}\left(\frac{p C i}{\mathrm{~L}}\right)
$$

where

$R s \quad$ is the measured sample ratio of ${ }^{129} \mathrm{I}$ atoms to

$$
{ }^{127} \text { I atoms, }
$$

$R b \quad$ is the ratio of the chemistry blank,

$W s \quad$ is the weight of ${ }^{127} \mathrm{I}$ in sample (in milligrams $[\mathrm{mg}]$ ),

Wc is the weight of ${ }^{127}$ I added as carrier (in $\mathrm{mg}$ ), and

$W t \quad$ is weight of sample (aliquot).

Laboratory results from previous studies (1990-2003) were reported by the PRIME Lab as the ratio of ${ }^{129} \mathrm{I}$ to ${ }^{127} \mathrm{I}$ and converted to concentrations in $\mathrm{pCi} / \mathrm{L}$ by using an equation described by Rao (1997):

$$
S_{T}=\frac{[R m(C c C v+S c S v)-C c C v C r] N}{f S v}
$$

where

$$
\begin{array}{cl}
S_{T} & \text { is the }{ }^{129} \mathrm{I} \text { concentration in atoms per liter of } \\
\text { water, }
\end{array}
$$

$$
\begin{aligned}
& \text { Sc is the concentration of iodine in } \mathrm{g} / \mathrm{L} \text { for } \\
& \text { sample, } \\
& S v \text { is the volume of the sample in } \mathrm{L} \text {, } \\
& N \quad \text { is Avogadro's number }\left(6.023 \times 10^{23}\right. \text { atoms/ } \\
& \text { mole }) \text {, and } \\
& f \text { is the formula weight for iodine }(126.9 \text { grams } \\
& \text { per mole). }
\end{aligned}
$$

The mass of the carrier given by the PRIME Lab is the product of carrier volume $\left(\mathrm{C}_{v}\right)$ and carrier concentration $\left(C_{C}\right)$ in milligrams. The concentration of iodine in most samples was less than $0.002 \mathrm{mg} / \mathrm{L}$, which was used for the concentration for all samples except those with estimated or reported concentrations.

\section{Guidelines for Interpretation of Analytical Results}

The guidelines for interpreting analytical results are based on an extension of a method proposed by Currie (1984) and are given in Mann and Beasley (1994b). Concentrations of ${ }^{129} \mathrm{I}$ are reported with an estimated sample standard deviation, $s$, which is obtained by propagating sources of analytical uncertainty in measurements. In this report, ${ }^{129} \mathrm{I}$ concentrations less than $3 s$ are considered less than a "reporting level" because the results are below the 95-percent probability of reporting true concentrations. The reporting level should not be confused with the analytical method detection limit, which is based on laboratory procedures (Bartholomay, 2013).

The laboratory calculations do not consider the concentration of iodine in the sample because the concentration typically is negligible; the concentrations were estimated in the equation (Rao, 1997) used for previous data from 1990 to 2003. Differences between the reported concentrations are similar between both equations when sample ratios are larger than carrier blank ratios; however, when ${ }^{129} / /{ }^{127} \mathrm{I}$ ratios of the samples are less than the ratio for the carrier blank sample, negative results occur for calculations based on equation 2. The PRIME Lab did not subtract the carrier blank ratios for the samples that had carrier blank ratios larger than sample ratios (Susan Ma, PRIME Lab, written commun., September 7, 2008), so no negative results occurred for the 2007, 2010-12, and 2017-18 data. This difference in calculation methods between 1990-2003 and results reported since 2003 should not affect the comparability of the data between these analyses periods since negative results are not considered. 


\section{Quality Assurance/Quality Control}

Quality assurance and reproducibility were assessed with replicate samples. Four sequential replicate samples were collected and submitted for AMS analyses along with the environmental samples.

Williams (1996) provided a detailed explanation of a method defined by Volk (1969) for determining the statistical equivalency of radiochemical-constituent concentrations in replicate pairs (where a replicate pair consists of the replicate sample and its associated environmental sample). In this method, statistical equivalence is determined in a specified confidence level. A value for the standard deviate, $\mathrm{Z}$, is calculated, and then the level of significance of the result is evaluated (evaluation of the level of significance assumes that the sample population is distributed normally). For this report, concentrations of individual constituents in replicate pairs were considered equivalent when the results were within two standard deviations of each other. At this confidence level (95-percent), the level of significance, determined from a standard normal probability curve, was 0.05 for a two-tailed test and corresponded to a $Z$-value of 1.96 .

The equation used to determine $Z$ was adapted from Volk (1969):

where

$$
Z=\frac{|x-y|}{\sqrt{\left(s_{x}\right)^{2}+\left(s_{y}\right)^{2}}}
$$

$x \quad$ is the concentration of a constituent in the environmental sample,

$y \quad$ is the concentration of the same constituent in the sequential replicate sample,

$s x$ is the standard deviation of $x$, and

sy is the standard deviation of $y$.

When the population is distributed normally and the standard deviation is known, the analytical results of replicate pairs can be considered statistically equivalent at the 95-percent confidence level if the Z-value is less than or equal to 1.96 . When the population is not distributed normally, which is often the case with radiochemical results (L. DeWayne Cecil, USGS, written commun., January 4, 2009) or an approximation of the standard deviation is used, a $Z$-value less than 1.96 must be considered as a guide when testing for equivalence (Williams, 1996).

The use of equation 3, therefore, is considered a guide in determining if the results of ${ }^{129} \mathrm{I}$ analyses of a replicate pair were equivalent. Table 1 lists the results and reported standard deviations for the analyses of ${ }^{129}$ I replicate pairs and the Z-values. Results for all four of the replicate pairs had Z-values less than or equal to 1.96 and can be considered statistically equivalent. Therefore, results for the replicate samples generally indicated that the sample collection and laboratory procedures used were appropriate for the data obtained.

\section{Concentrations of lodine-129 in the Eastern Snake River Plain Aquifer}

Thirty water samples were collected from the ESRP aquifer at wells in and around the INL in October 2017 and April 2018. All wells had ${ }^{129}$ I concentrations above the estimated background level of $0.0000054 \mathrm{pCi} / \mathrm{L}$ for the ESRP aquifer as calculated by Cecil and others (2003). Concentrations ranged from $0.000016 \pm 0.000001$ to $0.877+/$ $0.032 \mathrm{pCi} / \mathrm{L}$ (table 1; fig. 4).

Table 2 shows multiple ${ }^{129} \mathrm{I}$ concentrations in water from 26 wells for the 5 sampling events during 1990-2018, with mean concentrations shown for each sampling event for the 15 wells that were included in all 5 sampling events. The mean concentration of 15 wells decreased from 1.15 $\mathrm{pCi} / \mathrm{L}$ in $1990-91$ to 0.168 in $2017-18$. When considering the mean uncertainties, the concentrations from 2017-18 are approximately the same as in 2011-12. Overall, 20 of 27 wells showed decreases or no change in concentrations ranging from 0.0000003 to $0.189 \mathrm{pCi} / \mathrm{L}$ that are attributed to discontinuation of disposal of ${ }^{129} \mathrm{I}$ in wastewater after 1988 and to dilution and dispersion in the ESRP aquifer (table 3). Bartholomay (2009) compared 2003 results to the 2007 results and described areas where concentrations seemed to be decreasing or increasing. In the wells with concentrations that increased, it was concluded that the increases could be due to flow in the Big Lost River moving remnant perched water concentrations into the aquifer. Mirus and others (2011) indicated that streamflow from the Big Lost River provides local recharge to the shallow, intermediate and deep perched zones within about $150 \mathrm{~m}$ of the river and indicated other perched water dynamics including local snowmelt and anthropogenic sources (such as leaky pipes and drainage ditches) contribute to recharge of shallow and intermediate perched zones throughout much of INTEC. The results of the current study show that most of the wells within a 1-mi radius of the INTEC showed no change or slight decreases in concentration since the 2011-12 study (fig. 6), but of the three wells that showed increases, two were sampled in April 2018 following two large pulses of flow in the river at the Lincoln Boulevard bridge (13132535, fig. 1) during the months of May to July 2017 (45,201 acre-feet/day) and continuous flow from the end of September 2017 through March 2018 (13,805 acre-feet/day), which may have helped move remnant ${ }^{129} \mathrm{I}$ from the unsaturated zone to the aquifer. 
Table 1. Iodine-129 concentrations in groundwater, Idaho National Laboratory and vicinity, 2017-18.

[See figures 2 and 3 for well locations. Concentrations and analytical uncertainties are in picocuries per liter (pCi/L); uncertainties are one standard deviation. Date sampled: Month, day, year. Z-value: Result of the statistical test used to compare the replicate values. Abbreviations: NA, not applicable; QA, quality assurance]

\begin{tabular}{|c|c|c|c|c|}
\hline Sample identifier & Site No. & Date sampled & Concentrations (pCi/L) & Z-value \\
\hline CFA-1 & 433204112562001 & 04-11-2018 & $0.403 \pm 0.012$ & NA \\
\hline CFA-2 & 433144112563501 & $10-10-2017$ & $0.082 \pm 0.003$ & NA \\
\hline Cross Road & 432128113092701 & 04-10-2018 & $0.000016 \pm 0.000001$ & NA \\
\hline RWMC M14S & 433052113025001 & $10-10-2017$ & $0.016 \pm 0.001$ & NA \\
\hline USGS 11 & 432336113064201 & 04-09-2018 & $0.000066 \pm 0.000003$ & NA \\
\hline USGS 14 & 432019112563201 & $10-11-2017$ & $0.000018 \pm 0.000001$ & NA \\
\hline USGS 20 & 433253112545901 & 04-17-2018 & $0.056 \pm 0.002$ & NA \\
\hline USGS 37 & 433326112564801 & $10-04-2017$ & $0.171 \pm 0.006$ & NA \\
\hline USGS 38 & 433322112564301 & $04-16-2018$ & $0.140 \pm 0.005$ & NA \\
\hline USGS 42 & 433404112561301 & 04-19-2018 & $0.221 \pm 0.006$ & NA \\
\hline USGS 45 & 433402112561801 & $10-02-2017$ & $0.292 \pm 0.010$ & NA \\
\hline USGS 47 & 433407112560301 & $10-05-2017$ & $0.206 \pm 0.008$ & NA \\
\hline USGS 51 & 433350112560601 & 04-18-2018 & $0.133 \pm 0.004$ & NA \\
\hline USGS 52 & 433414112554201 & $10-04-2017$ & $0.151 \pm 0.006$ & NA \\
\hline USGS 57 & 433344112562601 & $10-02-2017$ & $0.144 \pm 0.006$ & NA \\
\hline USGS 67 & 433344112554101 & $10-04-2017$ & $0.877 \pm 0.032$ & 1.05 \\
\hline QA-6 & 433344112554101 & $10-04-2017$ & $0.931 \pm 0.040$ & NA \\
\hline USGS 77 & 433315112560301 & $10-03-2017$ & $0.372 \pm 0.013$ & 1.96 \\
\hline QA-3 & 433315112560301 & $10-03-2017$ & $0.408 \pm 0.013$ & NA \\
\hline USGS 82 & 433401112551001 & 04-17-2018 & $0.0073 \pm 0.0002$ & NA \\
\hline USGS 85 & 433246112571201 & 04-16-2018 & $0.079 \pm 0.002$ & NA \\
\hline USGS 104 & 432856112560801 & $10-12-2017$ & $0.0045 \pm 0.0004$ & NA \\
\hline USGS 106 & 432959112593101 & $10-19-2017$ & $0.027 \pm 0.001$ & NA \\
\hline USGS 111 & 433331112560501 & 04-17-2018 & $0.235 \pm 0.009$ & 0.08 \\
\hline QA-4 & 433331112560501 & 04-17-2018 & $0.236 \pm 0.008$ & NA \\
\hline USGS 112 & 433314112563001 & $10-03-2017$ & $0.239 \pm 0.008$ & NA \\
\hline USGS 113 & 433314112561801 & $04-17-2018$ & $0.402 \pm 0.011$ & NA \\
\hline USGS 114 & 433318112555001 & $10-03-2017$ & $0.129 \pm 0.006$ & NA \\
\hline USGS 116 & 433331112553201 & 04-17-2018 & $0.395 \pm 0.0150$ & NA \\
\hline USGS 124 & 432307112583101 & 04-09-2018 & $0.0022 \pm 0.0001$ & NA \\
\hline USGS 125 & 432602113052801 & $10-11-2017$ & $0.00039 \pm 0.00001$ & NA \\
\hline USGS 130 & 433130112562801 & $10-19-2017$ & $0.031 \pm 0.001$ & NA \\
\hline USGS 144 & 433021112552501 & 04-03-2018 & $0.000020 \pm 0.000001$ & 0.71 \\
\hline QA-8 & 433021112552501 & 04-03-2018 & $0.000019 \pm 0.000001$ & NA \\
\hline
\end{tabular}




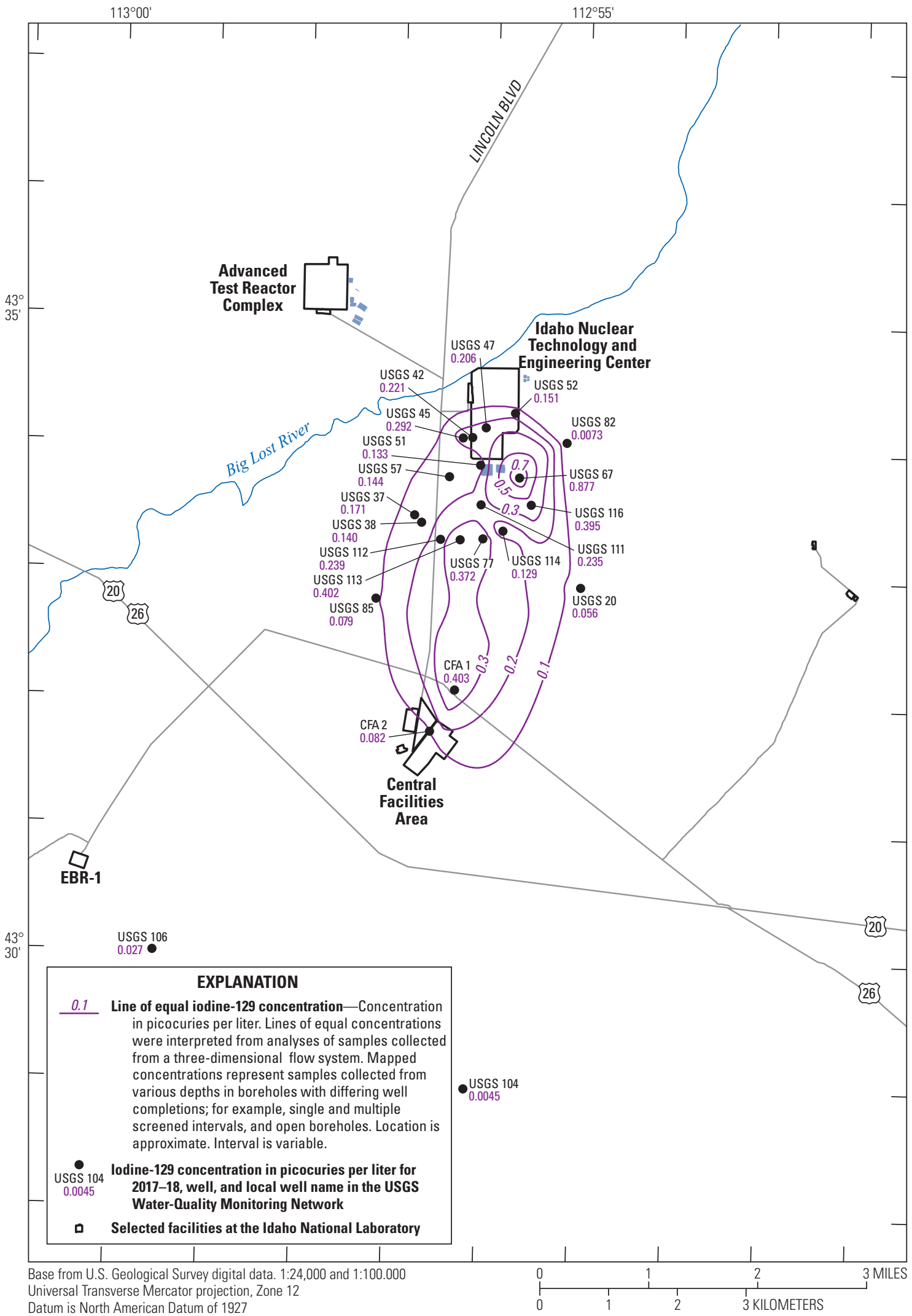

Figure 4. Areal distribution of iodine-129 in the eastern Snake River Plain aquifer at the Idaho National Laboratory, Idaho, 2017-18. 
Table 2. Concentrations of lodine-129 in water from selected wells, Idaho National Laboratory and vicinity, 1990-2018.

[See figures 2 and 3 for well locations. Concentrations and analytical uncertainties are in picocuries per liter (pCi/L); uncertainties are one standard deviation. Mean concentration calculated from the 15 wells with concentrations from all 5 sample periods. Abbreviation: NS, not sampled]

\begin{tabular}{|c|c|c|c|c|c|}
\hline Sample identifier & 1990-91 & 2003 & 2007 & 2011-12 & 2017-18 \\
\hline CFA-1 & $0.24 \pm 0.05$ & NS & $0.318 \pm .015$ & $0.37 \pm 0.017$ & $0.403 \pm 0.012$ \\
\hline CFA-2 & $0.10 \pm 0.03$ & NS & $0.131 \pm 0.006$ & $0.0798 \pm 0.0024$ & $0.082 \pm 0.003$ \\
\hline USGS 11 & $0.00001 \pm 0.000001$ & $0.000018 \pm 0.0000005$ & NS & $0.000046 \pm 0.0000025$ & $0.000066 \pm 0.000003$ \\
\hline USGS 14 & $0.00003 \pm 0.000002$ & $0.00004 \pm 0.000002$ & NS & $0.0000177 \pm 0.000001$ & $0.000018 \pm 0.000001$ \\
\hline USGS $20^{1}$ & $0.033 \pm 0.002$ & $0.026 \pm 0.0011$ & $0.0282 \pm 0.0009$ & $0.037 \pm 0.0021$ & $0.056 \pm 0.002$ \\
\hline USGS $37^{1}$ & $1.80 \pm 0.08$ & $0.452 \pm 0.025$ & $0.395 \pm 0.017$ & $0.31 \pm 0.016$ & $0.171 \pm 0.006$ \\
\hline USGS $38^{1}$ & $2.00 \pm 0.07$ & $0.556 \pm 0.019$ & $0.281 \pm 0.008$ & $0.202 \pm 0.018$ & $0.140 \pm 0.005$ \\
\hline USGS $42^{1}$ & $3.82 \pm 0.19$ & $0.216 \pm 0.0064$ & $0.325 \pm 0.01$ & $0.214 \pm 0.013$ & $0.221 \pm 0.006$ \\
\hline USGS 45 & $0.32 \pm 0.01$ & NS & NS & $0.359 \pm 0.012$ & $0.292 \pm 0.010$ \\
\hline USGS 47 & $0.83 \pm 0.04$ & $0.621 \pm 0.022$ & NS & $0.349 \pm 0.019$ & $0.206 \pm 0.008$ \\
\hline USGS $51^{1}$ & $0.28 \pm 0.01$ & $0.164 \pm 0.0071$ & $0.231 \pm 0.01$ & $0.151 \pm 0.01$ & $0.133 \pm 0.004$ \\
\hline USGS 52 & $0.38 \pm 0.03$ & NS & $0.284 \pm 0.014$ & $0.165 \pm 0.008$ & $0.151 \pm 0.006$ \\
\hline USGS $57^{1}$ & $1.38 \pm 0.07$ & $0.64 \pm 0.023$ & $0.521 \pm 0.023$ & $0.333 \pm 0.021$ & $0.144 \pm 0.006$ \\
\hline USGS 67 & $1.43 \pm 0.04$ & NS & $1.16 \pm 0.04$ & $1.02 \pm 0.04$ & $0.877 \pm 0.032$ \\
\hline USGS $77^{1}$ & $1.37 \pm 0.06$ & $0.586 \pm 0.0193$ & $0.71 \pm 0.04$ & $0.153 \pm 0.007$ & $0.372 \pm 0.013$ \\
\hline USGS $82^{1}$ & $0.119 \pm 0.002$ & $0.0112 \pm 0.0004$ & $0.011 \pm 0.0004$ & $0.007 \pm 0.0005$ & $0.0073 \pm 0.0002$ \\
\hline USGS $85^{1}$ & $1.64 \pm 0.08$ & $0.283 \pm 0.009$ & $0.173 \pm 0.006$ & $0.113 \pm 0.008$ & $0.079 \pm 0.002$ \\
\hline USGS $104^{1}$ & $0.0036 \pm 0.0001$ & $0.0049 \pm 0.0002$ & $0.005 \pm 0.00023$ & $0.027 \pm 0.007$ & $0.0045 \pm 0.0004$ \\
\hline USGS $106^{1}$ & $0.025 \pm 0.001$ & $0.034 \pm 0.001$ & $0.0274 \pm 0.0013$ & $0.0288 \pm 0.0012$ & $0.027 \pm 0.001$ \\
\hline USGS $111^{1}$ & $0.86 \pm 0.09$ & $0.138 \pm 0.007$ & $0.192 \pm 0.007$ & $0.166 \pm 0.009$ & $0.235 \pm 0.009$ \\
\hline USGS 112 & $2.40 \pm 0.25$ & $0.617 \pm 0.067$ & NS & $0.43 \pm 0.03$ & $0.239 \pm 0.008$ \\
\hline USGS $113^{1}$ & $3.25 \pm 0.14$ & $0.72 \pm 0.051$ & $0.75 \pm 0.04$ & $0.477 \pm 0.026$ & $0.402 \pm 0.011$ \\
\hline USGS $114^{1}$ & $0.28 \pm 0.01$ & $0.153 \pm 0.0063$ & $0.173 \pm 0.006$ & $0.141 \pm 0.004$ & $0.129 \pm 0.006$ \\
\hline USGS $116^{1}$ & $0.45 \pm 0.01$ & $0.069 \pm 0.0026$ & $0.144 \pm 0.005$ & $0.242 \pm 0.011$ & $0.395 \pm 0.0150$ \\
\hline USGS 124 & NS & $0.0023 \pm 0.0001$ & $0.00225 \pm 0.00007$ & $0.00186 \pm 0.0001$ & $0.0022 \pm 0.0001$ \\
\hline USGS 125 & NS & $0.00013 \pm 0.0000008$ & NS & $0.000293 \pm 0.00001$ & $0.00039 \pm 0.00001$ \\
\hline $\begin{array}{l}\text { Mean } \\
\text { concentration }\end{array}$ & $1.15 \pm 0.054$ & $0.270 \pm 0.012$ & $0.264 \pm 0.012$ & $0.173 \pm 0.010$ & $0.168 \pm 0.006$ \\
\hline
\end{tabular}

${ }^{1}$ Wells used for mean concentration values 
Table 3. Iodine-129 concentrations in groundwater wells located various distances from the Idaho Nuclear Technology and Engineering Center and changes in concentration from the 2011-12 study, Idaho National Laboratory and vicinity, Idaho.

[See figures 2 and 3 for well locations. Concentrations and analytical uncertainties are in picocuries per liter (pCi/L); analytical uncertainties are one standard deviation (s); combined standard uncertainties (uc) are 2 s. Abbreviations: NA, not applicable; NS, not sampled]

\begin{tabular}{|c|c|c|c|c|c|}
\hline $\begin{array}{c}\text { Sample } \\
\text { identifier }\end{array}$ & 2011-12 & 2017-18 & Change & $\mathbf{u}_{\mathrm{c}}$ & Trend \\
\hline \multicolumn{6}{|c|}{ I-mile radius of the INTEC } \\
\hline USGS 37 & $0.31 \pm 0.016$ & $0.171 \pm 0.006$ & -0.139 & 0.044 & Decrease \\
\hline USGS 38 & $0.202 \pm 0.018$ & $0.140 \pm 0.005$ & -0.062 & 0.046 & Decrease \\
\hline USGS 42 & $0.214 \pm 0.013$ & $0.221 \pm 0.006$ & 0.007 & 0.038 & No change \\
\hline USGS 45 & $0.359 \pm 0.012$ & $0.292 \pm 0.010$ & -0.067 & 0.044 & Decrease \\
\hline USGS 47 & $0.349 \pm 0.019$ & $0.206 \pm 0.008$ & -0.143 & 0.054 & Decrease \\
\hline USGS 51 & $0.151 \pm 0.01$ & $0.133 \pm 0.004$ & -0.018 & 0.028 & Decrease \\
\hline USGS 52 & $0.165 \pm 0.008$ & $0.151 \pm 0.006$ & -0.014 & 0.028 & Decrease \\
\hline USGS 57 & $0.333 \pm 0.021$ & $0.144 \pm 0.006$ & -0.189 & 0.054 & Decrease \\
\hline USGS 67 & $1.02 \pm 0.04$ & $0.877 \pm 0.032$ & -0.143 & 0.144 & Decrease \\
\hline USGS 77 & $0.153 \pm 0.007$ & $0.372 \pm 0.013$ & 0.219 & 0.04 & Increase \\
\hline USGS 82 & $0.007 \pm 0.0005$ & $0.0073 \pm 0.0002$ & 0.0003 & 0.0014 & No change \\
\hline USGS 111 & $0.166 \pm 0.009$ & $0.235 \pm 0.009$ & 0.069 & 0.036 & Increase \\
\hline USGS 112 & $0.43 \pm 0.03$ & $0.239 \pm 0.008$ & -0.191 & 0.076 & Decrease \\
\hline USGS 113 & $0.477 \pm 0.026$ & $0.402 \pm 0.011$ & -0.075 & 0.074 & Decrease \\
\hline USGS 114 & $0.141 \pm 0.004$ & $0.129 \pm 0.006$ & -0.012 & 0.02 & Decrease \\
\hline USGS 116 & $0.242 \pm 0.011$ & $0.395 \pm 0.0150$ & 0.153 & 0.052 & Increase \\
\hline \multicolumn{6}{|c|}{ 2-mile radius of the INTEC } \\
\hline USGS 20 & $0.037 \pm 0.0021$ & $0.056 \pm 0.002$ & 0.019 & 0.0082 & Increase \\
\hline USGS 85 & $0.113 \pm 0.008$ & $0.079 \pm 0.002$ & -0.034 & 0.02 & Decrease \\
\hline \multicolumn{6}{|c|}{3 -mile radius of the INTEC } \\
\hline CFA-1 & $0.37 \pm 0.017$ & $0.403 \pm 0.012$ & 0.033 & 0.058 & No change \\
\hline CFA-2 & $0.0798 \pm 0.0024$ & $0.082 \pm 0.003$ & 0.0022 & 0.0108 & No change \\
\hline USGS 130 & NS & $0.031 \pm 0.001$ & NA & NA & NA \\
\hline \multicolumn{6}{|c|}{ Greater than 3-mile radius of the INTEC } \\
\hline Cross Road & $0.0000066 \pm 0.0000009$ & $0.000016 \pm 0.000001$ & 0.0000094 & 0.0000019 & Increase \\
\hline RWMC M14S & NS & $0.016 \pm 0.001$ & NA & NA & NA \\
\hline USGS 11 & $0.000046 \pm 0.0000025$ & $0.000066 \pm 0.000003$ & 0.00002 & 0.000011 & Increase \\
\hline USGS 14 & $0.0000177 \pm 0.000001$ & $0.000018 \pm 0.000001$ & 0.0000003 & 0.000004 & No change \\
\hline USGS 104 & $0.027 \pm 0.007$ & $0.0045 \pm 0.0004$ & -0.0225 & 0.0148 & Decrease \\
\hline USGS 106 & $0.0288 \pm 0.0012$ & $0.027 \pm 0.001$ & -0.0018 & 0.0044 & Decrease \\
\hline USGS 124 & $0.00186 \pm 0.0001$ & $0.0022 \pm 0.0001$ & 0.00034 & 0.0004 & No change \\
\hline USGS 125 & $0.000293 \pm 0.00001$ & $0.00039 \pm 0.00001$ & 0.000097 & 0.00004 & Increase \\
\hline USGS 144 & NS & $0.000020 \pm 0.000001$ & $\mathrm{NA}$ & NA & NA \\
\hline
\end{tabular}




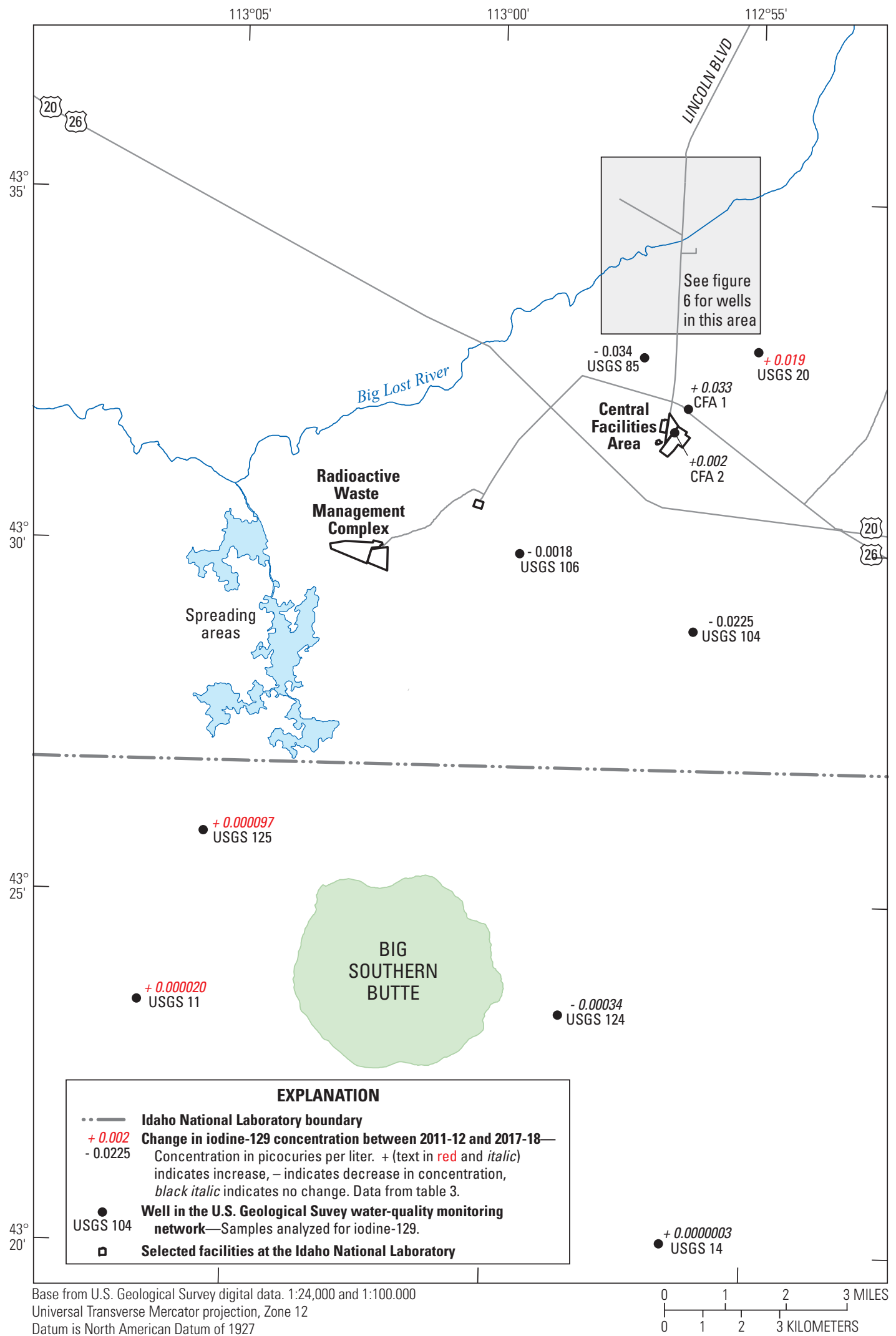

Figure 5. Change in concentration of iodine-129 between samples collected during 2011-12 and 2017-18, Idaho National Laboratory and vicinity, Idaho. 


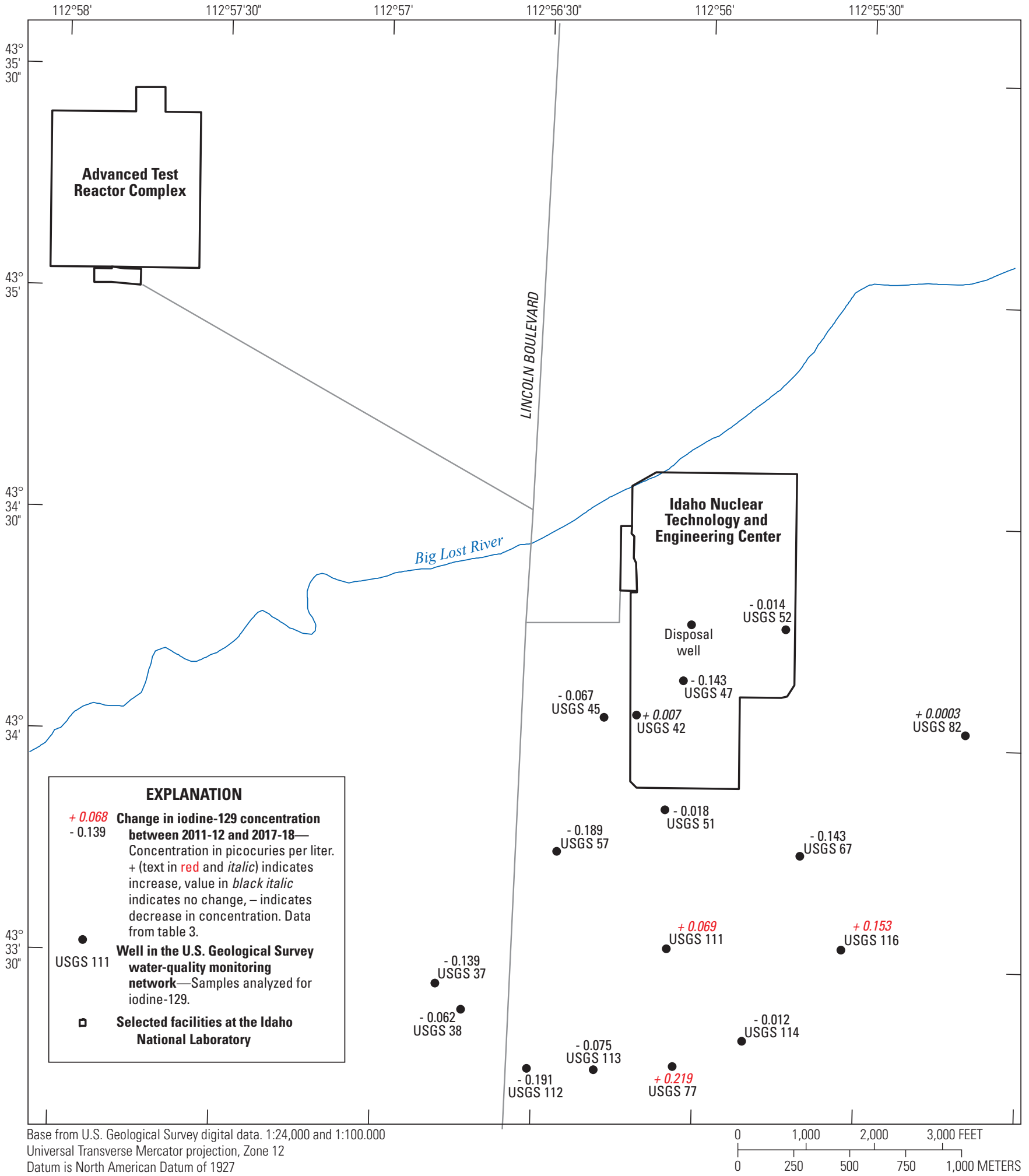

Figure 6. Change in concentration of iodine-129 between samples collected between 2011-12 and 2017-18 in the Idaho Nuclear Technology and Engineering Center area, Idaho. 
The largest ${ }^{129} \mathrm{I}$ concentration value for this study was at USGS 67, located southeast of the INTEC (table 1; fig. 4), at $0.877 \mathrm{pCi} / \mathrm{L}$, which continues a decreasing trend for this well (fig. 7). This decreasing trend is consistent with decreasing trends for tritium, strontium-90, chloride, sodium, and sulfate for this well (Davis and others, 2015, tables 5 and 7). Continuing to the southeast is USGS 116, with a concentration of $0.395 \mathrm{pCi} / \mathrm{L}$, an increase of $0.153 \mathrm{pCi} / \mathrm{L}$ from the $2011-12$ study and the second largest increase in this study. This well and well USGS 20 further to the southeast show increasing trends (fig. 7). Davis and others (2015) suggested that the aquifer southeast of the INTEC has lower transmissivity which may account for the slower movement of wastewater to the wells, and the resulting increasing concentrations in these wells to the southeast of INTEC may be remnant water from periods of time with large amounts of disposal. Both USGS 20 and 116 also show increasing concentration trends for chloride (Davis and others, 2015, table 7).

The well with the largest increase in concentration was USGS 77, with an increase of 0.219 pCi/L (table 3; fig. 6). The reason for this increase is unclear, though a similar increase occurred during the 2007 study with a subsequent decrease in 2011-12, and the overall trend for this site continues to show a decrease in ${ }^{129}$ I concentration values (fig. 7). Both the increases occurred after wet periods in 2006 and 2017, so it is possible this particular well had a pulse of wastewater contaminants moved to it; it showed similar increases in sodium in 2007 and 2017-18.

Although most of the wells near the INTEC showed decreases of ${ }^{129} \mathrm{I}$, about half of the wells located beyond a 1-mi radius ( 8 of 11) showed slight increases in concentrations between 2011-12 and 2017-18 (table 3; figs. 5 and 6). The amount of increase for four of these wells fell within the range of uncertainty for the reported analytical results thereby resulting in no statistical change. Only wells USGS 85,104 , and 106 showed a slight decrease in concentration. These concentration increases or decreases may be related to variable discharge rates of wastewater that moved to these well locations as a mass of water from a particular disposal period as discussed in Bartholomay (2013). The highest concentrations of ${ }^{129} \mathrm{I}$ probably were in wastewater discharged in 1958 and 1978 (modified from U.S. Department of Energy, 2004, appendix D). Therefore, when water reaches a well from discharge in 1958 and 1978, the concentration of the sample most likely would be greater than concentrations in samples of water discharged during other periods. Data from wells USGS 11 and USGS 14 from Hall (2006) somewhat support this idea because ${ }^{129} \mathrm{I}$ concentrations for these two wells were less in 1998 than during the 1990-91 and 2003 sample periods.

Previous studies have found that mobility of different isotopes in the ESRP is variable and timing of peak migration of these isotopes at sites on the INL can have large differences in arrival times. Cecil and others (2000) indicated that 1958 peak disposal of chlorine-36 probably reached USGS 11 in 1984 and reached USGS 14 in 1987. Using similar timing of movement of wastewater, the 2018 samples would have been primarily from wastewater discharged in 1994 for USGS 11 and 1991 for USGS 14, which would have been after the primary disposal of ${ }^{129} \mathrm{I}$ into the aquifer. Beasley and others (1998) examined the relative mobility of several isotopes disposed at the INTEC, and they concluded that chlorine-36 behaves conservatively in the basalt; however, ${ }^{129} \mathrm{I}$ is attenuated by sorption with other ionic species, and probably moves more slowly in the system. Busenberg and others (2001, table 8 and fig. 25) calculated the age of the young fraction of groundwater and relative flow rates for several of the wells, at and south of the INL; and the age and flow velocity to USGS 11 and USGS 125 were younger and faster than the age and flow velocity to USGS 124 and USGS 14, which could account for the observed increase in concentrations for USGS 11 and USGS 125 and don't change for USGS 124 and USGS 14. Accurately predicting the first arrival of peak concentrations with the limited sample periods is difficult because of the uncertainty of ${ }^{129} \mathrm{I}$ concentrations in wastewater discharged prior to 1976 and the uncertainty of flow movement in the basaltic aquifer system. 
CFA 1

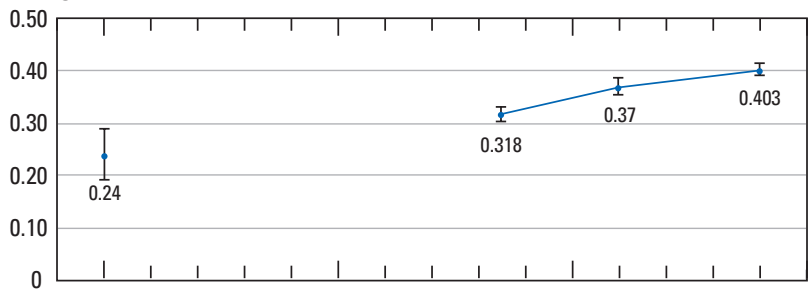

USGS 20

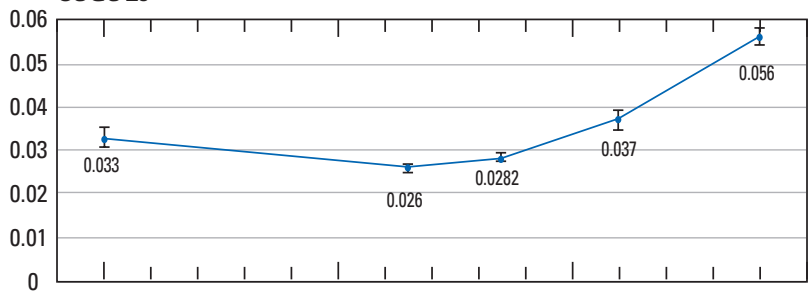

USGS 67
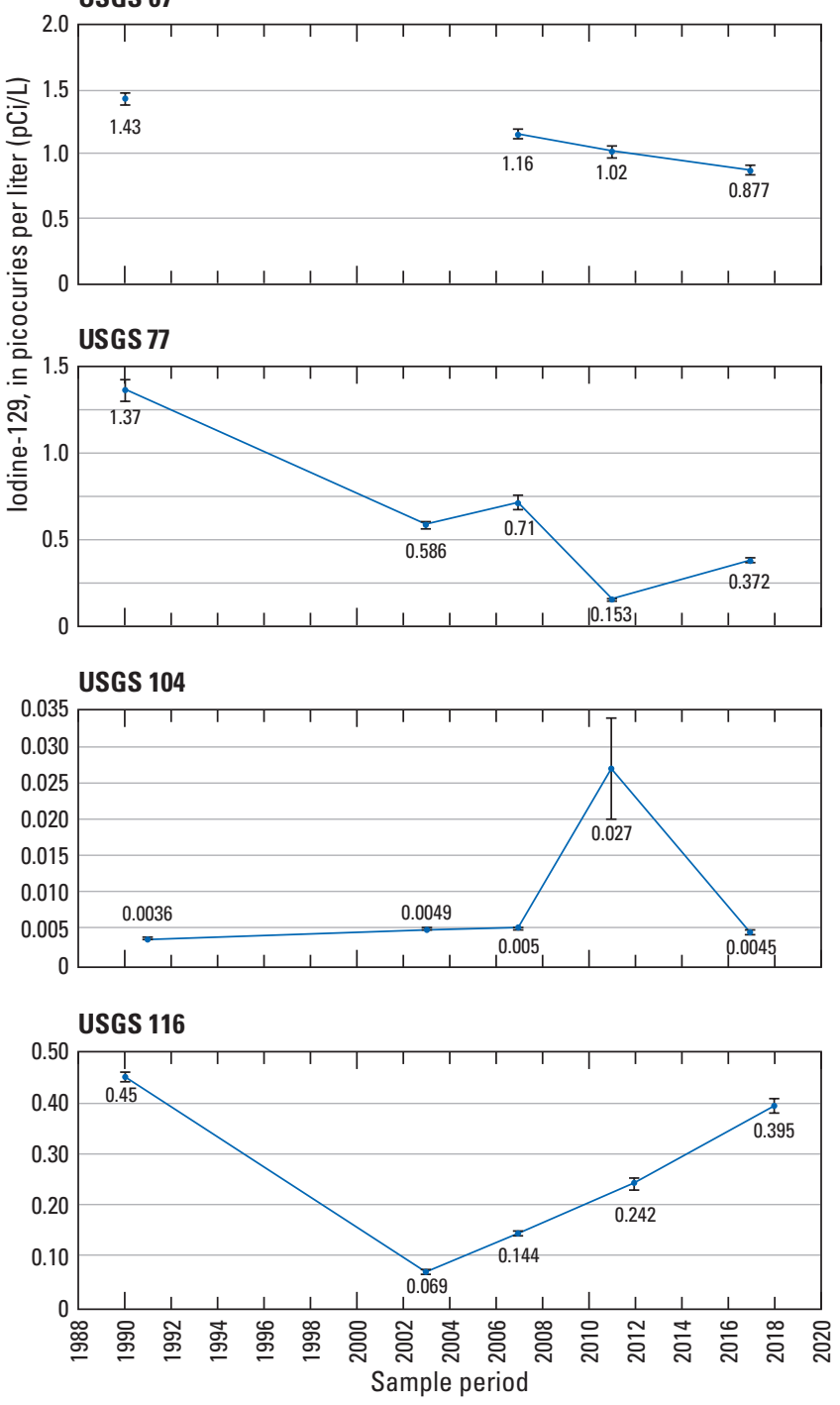

Figure 7. Concentration trends of iodine-129 at selected wells at and near the Idaho National Laboratory, Idaho.

\section{Summary}

From 1953 to 1988, the Idaho National Laboratory (INL) in southeastern Idaho generated wastewater containing approximately 0.941 curies of iodine- $129\left({ }^{129} \mathrm{I}\right)$. This wastewater was a byproduct of fuel reprocessing activities at the Idaho Nuclear Technology and Engineering Center (INTEC) at the INL. The majority was discharged directly into the eastern Snake River Plain (ESRP) aquifer through a deep disposal well until 1984; however, some wastewater also was discharged into unlined infiltration ponds or leaked from distribution systems below the INTEC.

The U.S. Geological Survey (USGS) conducted monitoring programs for ${ }^{129} \mathrm{I}$ in the ESRP aquifer at the INL in 1977, 1981, 1986, 1990-91, 2003, 2007, and 2010-12 prior to sample collection in 2017-18. Some additional sampling was done in the 1990s to determine an estimated background concentration of ESRP water of 0.0000054 picocuries per liter $(\mathrm{pCi} / \mathrm{L})$. Current ${ }^{129} \mathrm{I}$ concentrations in the ESRP aquifer at the INL are compared to the background concentration and to the U.S. Environmental Protection Agency's (USEPA) maximum contaminant level (MCL) of $1 \mathrm{pCi} / \mathrm{L}$.

In 2017-18, the USGS, in cooperation with the U.S. Department of Energy, collected samples for ${ }^{129}$ I from 30 wells that are used to monitor the ESRP aquifer. Four replicate samples were collected as a measure of quality assurance. Concentrations of ${ }^{129} \mathrm{I}$ in the aquifer ranged from $0.000016 \pm$ 0.000001 to $0.877 \pm 0.032 \mathrm{pCi} / \mathrm{L}$, and concentrations generally decreased in wells near the INTEC from samples collected previously. The mean concentration of 15 wells sampled during 5 different sample periods decreased from $1.15 \mathrm{pCi} / \mathrm{L}$ in $1990-91$ to $0.168 \mathrm{pCi} / \mathrm{L}$ in $2017-18$, with concentration trends decreasing or holding steady in 11 wells and increasing in 4 wells. Overall, 20 of 27 wells showed decreases or no change in concentrations ranging from 0.0000003 to 0.189 $\mathrm{pCi} / \mathrm{L}$ that are attributed to discontinuation of disposal of ${ }^{129} \mathrm{I}$ in wastewater after 1988 and to dilution and dispersion in the ESRP aquifer. All wells had concentrations less than the USEPA's MCL.

Increases in concentrations for wells within $1 \mathrm{mi}$ of INTEC were attributed to either more recharge near INTEC from episodic flow in the Big Lost River and/or from local snowmelt and anthropogenic sources moving remnant wastewater, or from lower transmissivities in an area southeast of the facility.

Although most wells near the INTEC sampled in 2017-18 showed decreases in concentrations compared with previously collected data, some wells locate south of the INL showed slight increases. These slight increases are probably related to variable discharge rates of wastewater that eventually have moved to these well locations as a mass of water from a particular disposal period. 


\section{Acknowledgment}

The authors gratefully acknowledge efforts by the U.S. Geological Survey Idaho National Laboratory hydrologic technicians for their diligence in collecting all requested samples.

\section{References Cited}

Ackerman, D.J., 1991, Transmissivity of the Snake River Plain aquifer at the Idaho National Engineering Laboratory, Idaho: U.S. Geological Survey Water-Resources Investigations Report 91-4058 (DOE/ID-22097), 35 p. [Also available at https://pubs.er.usgs.gov/publication/ wri914058.]

Barraclough, J.T., Lewis, B.D., and Jensen, R.G., 1982, Hydrologic conditions at the Idaho National Engineering Laboratory, Idaho, emphasis 1974-1978: U.S. Geological Survey Water Supply Paper 2191, 52 p. [Also available at https://pubs.er.usgs.gov/publication/wsp2191.]

Bartholomay, R.C., 1993, Concentrations of tritium and strontium-90 in water from selected wells at the Idaho National Engineering Laboratory after purging one, two, and three borehole volumes: U.S. Geological Survey WaterResources Investigations Report 93-4201 (DOE/ID-22111), 21 p. [Also available at https://pubs.er.usgs.gov/publication/ wri934201.]

Bartholomay, R.C., 2009, Iodine-129 in the Snake River Plain aquifer at and near the Idaho National Laboratory, Idaho, 2003 and 2007: U.S. Geological Survey Scientific Investigations Report 2009-5088 (DOE/ID-22208), 28 p. [Also available at https://pubs.er.usgs.gov/publication/ sir20095088.]

Bartholomay, R.C., 2013, Iodine-129 in the eastern Snake River Plain aquifer at and near the Idaho National Laboratory, Idaho, 2010-12: U.S. Geological Survey Scientific Investigations Report 2013-5195 (DOE/ ID-22225), 22 p. [Also available at https://doi.org/10.3133/ sir20135195.]

Bartholomay, R.C., Maimer, N.V., and Wehnke, A.J., 2014, Field methods and quality-assurance plan for water-quality activities and water-level measurements, U.S. Geological Survey, Idaho National Laboratory, Idaho: U.S. Geological Survey Open-File Report 2014-1146 (DOE/ID-22230), 66 p. [Also available at http://dx.doi.org/ofr20141146.]
Bartholomay, R.C., Maimer, N.V., Rattray, G.W., and Fisher, J.C., 2017, An update of hydrologic conditions and distribution of selected constituents in water, eastern Snake River Plain aquifer and perched groundwater zones, Idaho National Laboratory, Idaho, emphasis 2012-15: U.S. Geological Survey Scientific Investigations Report 20175021, (DOE/ID-22242), 87 p. [Also available at https://doi. org/10.3133/sir20175021.]

Bartholomay, R.C., Tucker, B.J., Ackerman, D.J., and Liszewski, M.J., 1997, Hydrologic conditions and distribution of selected radiochemical and chemical constituents in water, Snake River Plain aquifer, Idaho National Engineering Laboratory, Idaho, 1992 through 1995: U.S. Geological Survey Water-Resources Investigations Report 97-4086 (DOE/ID-22137), 57 p. [Also available at https://pubs.er.usgs.gov/publication/ wri974086.]

Beasley, T.M., Dixon, P.R., and Mann, L.J., 1998, Technetium-99, uranium-236, and neptunium-237 in the Snake River Plain aquifer at the Idaho National Engineering and Environmental Laboratory, Idaho Falls, Idaho: Environmental Science and Technology, v. 32, p. 38753881 .

Busenberg, E., Plummer, L.N., and Bartholomay, R.C., 2001, Estimated age and source of the young fraction of ground water at the Idaho National Engineering and Environmental Laboratory: U.S. Geological Survey Water-Resources Investigations Report 01-4265 (DOE/ID-22177), 144 p. [Also available at https://pubs.er.usgs.gov/publication/ wri014265.]

Caffee, M.W., 2019, Quality assurance requirements for $36 \mathrm{Cl}$ and 129I accelerator mass spectrometry: Purdue Science, Purdue Rare Isotope Measurement Laboratory, http://www. physics.purdue.edu/primelab/user-information/qualitycontrol.php.

Cahn, L.S., Abbott, M.L., Keck, J.F., Martian, Peter, Schafer, A.L., and Swenson, M.C., 2006, Operable unit 3-14 Tank Farm soil and groundwater remedial investigation/ baseline risk assessment: U.S. Department of Energy Idaho Operations Office Publication, DOE/NE-ID-11227, rev. 0 , variously paginated, https://ar.icp.doe.gov/images/ pdf/200604/2006042700836TUA.pdf.

Cecil, L.D., Hall, L.F., and Green, J.R., 2003, Reevaluation of background iodine-129 concentrations in water from the Snake River Plain aquifer, Idaho, 2003: U.S. Geological Survey Water-Resources Investigations Report 03-4106 (DOE/ID-22186), 18 p. [Also available at https://pubs. er.usgs.gov/publication/wri034106.] 
Cecil, L.D., Welhan, J.A., Green, J.R., Frape, S.K., and Sudicky, E.R., 2000, Use of chlorine-36 to determine regional-scale aquifer dispersivity, eastern Snake River Plain aquifer, Idaho/USA: Nuclear Instruments and Methods in Physics Research, Section B 172, p. 679-687, https://doi.org/10.1016/S0168-583X(00)00216-0.

Currie, L.A., 1984, Lower limit of detection-Definition and elaboration of a proposed position for radiological effluent and environmental measurements: U.S. Nuclear Regulatory Commission NUREG/CR-4007, 139 p., https:/www.osti. gov/servlets/purl/6411049.

Davis, L.C., Bartholomay, R.C., Fisher, J.C., and Maimer, N.V., 2015, Water-quality characteristics and trends for selected wells possibly influenced by wastewater disposal at the Idaho National Laboratory, Idaho, 1981-2012: U.S. Geological Survey Scientific Investigations Report 20155003 (DOE/ID-22233), 106 p. [Also available at https:// pubs.usgs.gov/sir/2015/5003/.]

Duke, C.L., Roback, R.C., Reimus, P.W., Bowman, R.S., McLing, T.L., Baker, K.E., and Hull, L.C., 2007, Elucidation of flow and transport processes in a variably saturated system of interlayered sediment and fractured rock using tracer tests: Vadose Zone Journal, v. 6, no. 4, p. 855-867, https://dl.sciencesocieties.org/publications/vzj/ abstracts/6/4/855. https://doi.org/10.2136/vzj2006.0102.

EG\&G Idaho, Inc., 1979, Radioactive waste management information for 1978: U.S. Department of Energy Report IDO-10055, v. 78, 291 p.

Forbes, J.R., Ansley, S.L., and Leecaster, Molly, 2007, INTEC groundwater monitoring report (2006): U.S. Department of Energy, Idaho Operations Office Publication, DOE/ ID-11301, rev. 0, 134 p., https://ar.icp.doe.gov/images/ pdf/200703/2007031900151TUA.pdf.

Garabedian, S.P., 1986, Application of a parameter-estimation technique to modeling the regional aquifer underlying the eastern Snake River Plain, Idaho: U.S. Geological Survey Water Supply Paper 2278, 60 p. [Also available at https:// pubs.er.usgs.gov/publication/wsp2278.]

Hall, L.F., 2006, Concentrations of selected trace metals, common ions, nutrients, and radiological analytes in ground water from selected sites, Snake River Plain aquifer, south of the Idaho National Laboratory, Idaho: State of Idaho Department of Environmental Quality Division of INL Oversight and Radiation Control, OP-06-03, 28 p, http:// www.deq.idaho.gov/media/553383-selected_trace_metals. pdf.
Knobel, L.L., 2006, Evaluation of well-purging effects on water-quality results for samples collected from the Eastern Snake River Plain aquifer underlying the Idaho National Laboratory, Idaho: U.S. Geological Survey Scientific Investigations Report 2006-5232 (DOE/ID-22200), 52 p. [Also available at https://pubs.usgs.gov/sir/2006/5232/.]

Lewis, B.D., and Jensen, R.G., 1985, Hydrologic conditions at the Idaho National Engineering Laboratory, Idaho-19791981 update: U.S. Geological Survey Hydrologic Atlas 674 (HA-674), 34 hydrographic charts. [Also available at https://pubs.er.usgs.gov/publication/ha674.]

Litteer, D.L., 1988, Idaho National Engineering Laboratory radioactive waste management information for 1987: U.S. Department of Energy, Waste Management Programs Division, Idaho Operations Office Publication, DOE/ ID-10055, v. 87, 530 p.

Litteer, D.L., and Reagan, B.D., 1989, Idaho National Engineering Laboratory radioactive waste management information for 1988: U.S. Department of Energy, Waste Management Programs Division, Idaho Operations Office Publication, DOE/ID-10055, v. 88, 510 p.

Mann, L.J., 1986, Hydraulic properties of rock units and chemical quality of water for INEL-1-A 10,365-foot deep test hole drilled at the Idaho National Engineering Laboratory, Idaho: U.S. Geological Survey Water-Resources Investigations Report 86-4020 (DOE/ID-22070), 23 p. [Also available at https://pubs.er.usgs.gov/publication/ wri864020.]

Mann, L.J., and Beasley, T.M., 1994a, Background concentrations of 129I in ground and surface water, eastern Snake River Plain, Idaho-1992: Journal of the Idaho Academy of Science, v. 30, no. 2, p. 75-87.

Mann, L.J., and Beasley, T.M., 1994b, Iodine-129 in the Snake River Plain aquifer at the Idaho National Engineering Laboratory, Idaho, 1990-1991: U.S. Geological Survey Water-Resources Investigations Report 94-4053 (DOE/ ID-22115), 27 p. [Also available at https://pubs.er.usgs.gov/ publication/wri944053.]

Mann, L.J., Chew, E.W., Morton, J.S., and Randolph, R.B., 1988, Iodine-129 in the Snake River Plain aquifer at the Idaho National Engineering Laboratory, Idaho: U.S. Geological Survey Water-Resources Investigations Report 88-4165 (DOE/ID-22076), 27 p. [Also available at https:// pubs.er.usgs.gov/publication/wri884165.]

Mirus, B.B., Perkins, K.S., and Nimmo, J.R., 2011, Assessing controls on perched saturated zones beneath the Idaho Nuclear Technology and Engineering Center, Idaho: U.S. Geological Survey Scientific Investigations Report 20115222 (DOE/ID-22216), 20 p. [Also available at https://pubs. usgs.gov/sir/2011/5222.] 
Nimmo, J.R., Perkins, K.S., Rose, P.A., Rousseau, J.P., Orr, B.R., Twining, B.V., and Anderson, S.R., 2002, Kilometerscale rapid transport of naphthalene sulfonate tracer in the unsaturated zone at the Idaho National Engineering and Environmental Laboratory: Vadose Zone Journal, v. 1, no. 1, p. 89-101, https://wwwrcamnl.wr.usgs.gov/uzf/abs_pubs/ papers/VZJ.1.89.pdf. https://doi.org/10.2136/vzj2002.8900.

Purdue Rare Isotope Measurement Laboratory, 2019, Welcome to Prime Lab: Purdue University, website, accessed April 30, 2019 at https://www.physics.purdue.edu/primelab/.

Purdue Rare Isotope Measurement Laboratory, 2019, What is AMS?: Purdue University, web, accessed April 30, 2019 at http://www.physics.purdue.edu/primelab/ams/index.php.

Rao, U., 1997, Sources, reservoirs and pathways of anthropogenic 129I in western New York: Rochester, New York, University of Rochester, PhD. Dissertation, 147 p.

Robertson, J.B., Schoen, Robert, and Barraclough, J.T., 1974, The influence of liquid waste disposal on the geochemistry of water at the National Reactor Testing Station, Idaho1952-1970: U.S. Geological Survey Open-File Report 73-238 (IDO-22053), 231 p. [Also available at https://pubs. er.usgs.gov/publication/ofr73238.]

Shanklin, D.E., Forbes, J.R., and Lawrence, S.D., 2017, Fiscal year 2016 annual report for operable unit 3-14-Tank farm soil and INTEC groundwater: U.S. Department of Energy, Idaho Operations Office, DOE/ID-11563, Rev. 0, 46 p.

Sharma, Pankaj, Elmore, David, Miller, Thomas, and Vogt, Stephan, 1997, The 129I AMS program at PRIME lab: Proceedings of Section B of Nuclear Instruments and Methods, v. 123, p. 347-351.

Sharma, P., Bourgeois, M., Elmore, D., Granger, D.E., Lipschutz, M.E., Ma, X., Miller, T.E., Mueller, K.A., Rickey, F.A., Simms, P., and Vogt, S., 2000, PRIME lab AMS performance-Upgrades and research applications: Nuclear Instruments \& Methods in Physics Research, Section B, Beam Interactions with Materials and Atoms, v. 172, no. 1-4, p. 112-123, https://doi.org/10.1016/S0168$583 X(00) 00132-4$.

U.S. Department of Energy, 2004, Monitoring report decision summary for operable unit 3-13, group 5, Snake River Plain aquifer: U.S. Department of Energy Idaho Operations Office Publication, DOE/ID-11098, rev. 1 , variously paginated, https://ar.icp.doe.gov/images/ pdf/200710/2007100400386TUA.pdf.
U.S. Department of Energy, 2007, Waste area group 10Operable unit 10-08 - Remedial investigation/feasibility study annual status report for fiscal year 2006: U.S. Department of Energy Idaho Operations Office Publication, DOE/ID-11297, rev. 0, 245 p., https://www.osti.gov/ biblio/910308.

U.S. Department of Energy, 2008, Waste area group 10, operable unit 10-08, annual monitoring status report for fiscal year 2007: U.S. Department of Energy Idaho Operations Office Publication, DOE/ID-11355, rev. 0, 123 p., https://www.osti.gov/biblio/978854.

U.S. Department of Energy, 2012, Fiscal year 2011 annual operations and maintenance report for operable unit 3-14-Tank farm soil and INTEC groundwater: U.S. Department of Energy Idaho Operations Office Publication, DOE/ID-11462, rev. 0, 140 p., https://ar.icp.doe.gov/owa/ getimage_2?F_PAGE $=1 \& \mathrm{~F} \_D O C=D O E / I D-11462 \& \mathrm{~F}$ $\mathrm{REV}=0$.

U.S. Environmental Protection Agency, 2015, National primary drinking water regulation table: U.S. Environmental Protection Agency, Office of Water Supply, EPA 816-F-09-004, accessed October 31, 2019 at https:// www.epa.gov/sites/production/files/2015-09/documents/ guide_radionuclides_table-betaphotonemitters.pdf

U.S. Geological Survey, 1985, National water summary, 1984-hydrologic events, selected water-quality trends and ground-water resources: U.S Geological Survey WaterSupply Paper 2275, 467 p., https://pubs.er.usgs.gov/ publication/wsp2275.

U.S. Geological Survey, 2019, Idaho National Laboratory project office publications list: U.S. Geological Survey, accessed October 31, 2019 at https://prd-wret.s3-us-west-2. amazonaws.com/assets/palladium/production/s3fs-public/ atoms/files/INL_Bibliography.pdf.

U.S. Geological Survey, variously dated, National field manual for the collection of water-quality data: U.S. Geological Survey Techniques of Water-Resources Investigations, Book 9, Chapters A1-A9. [Also available at https://pubs. water.usgs.gov/twri9A.]

Volk, W., 1969, Applied statistics for engineers (2nd ed.): New York, McGraw-Hill Book Company, 415 p.

Williams, L.M., 1996, Evaluation of quality assurance/quality control data collected by the U.S. Geological Survey for water-quality activities at the Idaho National Engineering Laboratory, Idaho, 1989 through 1993: U.S. Geological Survey Water-Resources Investigations Report 96-4148 (DOE/ID-22129), 116 p. [Also available at https://pubs. er.usgs.gov/publication/wri964148.] 
Publishing support provided by the U.S. Geological Survey Science Publishing Network, Tacoma Publishing Service Center

For more information concerning the research in this report, contact the Director, Idaho Water Science Center

U.S. Geological Survey

230 Collins Rd

Boise, Idaho 83702-4520

https://www.usgs.gov/centers/id-water 


\section{$\frac{\mathbb{2}}{3}$}

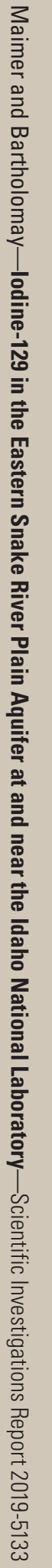

ISSN 2328-0328 (online)

https://doi.org/10.3133/sir20195133 